\title{
Indian Monsoon-ENSO Relationship on Interdecadal Timescale
}

\author{
V. KRISHNAMURTHY \\ Center for Ocean-Land-Atmosphere Studies, Institute of Global Environment and Society, Inc., Calverton, Maryland \\ B. N. Goswami \\ Centre for Atmospheric and Oceanic Sciences, Indian Institute of Science, Bangalore, India
}

(Manuscript received 2 November 1998, in final form 8 April 1999)

\begin{abstract}
Empirical evidence is presented to support a hypothesis that the interdecadal variation of the Indian summer monsoon and that of the tropical SST are parts of a tropical coupled ocean-atmosphere mode. The interdecadal variation of the Indian monsoon rainfall (IMR) is strongly correlated with the interdecadal variations of various indices of El Niño-Southern Oscillation (ENSO). It is also shown that the interannual variances of both IMR and ENSO indices vary in phase and follow a common interdecadal variation. However, the correlation between IMR and eastern Pacific SST or between IMR and Southern Oscillation index (SOI) on the interannual timescale does not follow the interdecadal oscillation. The spatial patterns of SST and sea level pressure (SLP) associated with the interdecadal variation of IMR are nearly identical to those associated with the interdecadal variations of ENSO indices. As has been shown earlier in the case of ENSO, the global patterns associated with the interdecadal and interannual variability of the Indian monsoon are quite similar.

The physical link through which ENSO is related to decreased monsoon rainfall on both interannual and interdecadal timescales has been investigated using National Centers for Environmental Prediction-National Center for Atmospheric Research reanalysis products. The decrease in the Indian monsoon rainfall associated with the warm phases of ENSO is due to an anomalous regional Hadley circulation with descending motion over the Indian continent and ascending motion near the equator sustained by the ascending phase of the anomalous Walker circulation in the equatorial Indian Ocean. It is shown that, to a large extent, both the regional Hadley circulation anomalies and Walker circulation anomalies over the monsoon region associated with the strong (weak) phases of the interdecadal oscillation are similar to those associated with the strong (weak) phases of the interannual variability. However, within a particular phase of the interdecadal oscillation, there are several strong and weak phases of the interannual variation. During a warm eastern Pacific phase of the interdecadal variation, the regional Hadley circulation associated with El Niño reinforces the prevailing anomalous interdecadal Hadley circulation while that associated with La Niña opposes the prevailing interdecadal Hadley circulation. During the warm phase of the interdecadal oscillation, El Niño events are expected to be strongly related to monsoon droughts while La Niña events may not have significant relation. On the other hand, during the cold eastern Pacific phase of the interdecadal SST oscillation, La Niña events are more likely to be strongly related to monsoon floods while El Niño events are unlikely to have a significant relation with the Indian monsoon. This picture explains the observation that the correlations between IMR and ENSO indices on the interannual timescale do not follow the interdecadal oscillation as neither phase of the interdecadal oscillation favors a stronger (or weaker) correlation between monsoon and ENSO indices.
\end{abstract}

\section{Introduction}

The Indian summer monsoon is known to have gone through alternating epochs of above-normal and belownormal conditions, each lasting about three decades. The interdecadal variability is evident in various monsoon parameters such as the all India monsoon rainfall (IMR)

Corresponding author address: Dr. V. Krishnamurthy, Center for Ocean-Land-Atmosphere Studies, Institute of Global Environment and Society Inc., 4041 Powder Mill Rd., Suite 302, Calverton, MD 20705.

E-mail: krishna@cola.iges.org
(Parthasarathy et al. 1994; Kripalani and Kulkarni 1997; Kripalani et al. 1997; Webster et al. 1998), the frequency of cyclones in the Indian monsoon region (Joseph 1976), the homogeneous monsoon rainfall based on subdivisions covering the northwestern and central parts of India (Parthasarathy et al. 1993), and circulation features such as the April position of the 500-hPa ridge (Kripalani et al. 1997). The mean rainfall during the periods 1871-1900 and 1931-60 was above the long-term mean while that during the periods $1901-30$ and 1961-90 was below the long-term mean, with relatively sharp transitions around 1900, 1930, and 1960. Several recent studies (Allan 1993; Allan et al. 1995; Kachi and Nitta 1997; Zhang et al. 1997) have shown that El Niño- 
Southern Oscillation (ENSO) is part of an interdecadal variability. Zhang et al. (1997, hereafter ZWB) showed that the interdecadal variability in the tropical Pacific is strongly related to the interdecadal variability in the North Pacific that was discussed in earlier studies (Tanimoto et al. 1993; Graham 1994; Graham et al. 1994; Kawamura 1994; Kachi and Nitta 1997). They also showed that the structure of the interdecadal variability is very similar to the interannual El Niño-Southern Oscillation (ENSO) mode. The ENSO-like interdecadal variability may be considered as a coupled ocean-atmosphere mode of oscillation for which different coupled mechanisms have been proposed ( $\mathrm{Gu}$ and Philander 1997; Latif et al. 1997; Latif 1998; Knutson and Manabe 1998; Meehl et al. 1998).

Are the interdecadal variability associated with the ENSO and that with the Indian monsoon related? There is empirical evidence showing that the two may be related. Kripalani and Kulkarni (1997) showed that there are more El Niño-related droughts in the decades when the Indian monsoon is generally below normal than during the decades when the Indian monsoon is generally above normal. Mehta and Lau (1997) have shown that the low-pass-filtered (attenuating all periods shorter than $24 \mathrm{yr}$ ) IMR and sea surface temperature (SST) anomalies over the so-called Niño-3 region of the eastern Pacific $\left(150^{\circ}-90^{\circ} \mathrm{W}\right.$ and $\left.5^{\circ} \mathrm{S}-5^{\circ} \mathrm{N}\right)$ are negatively correlated. If the ENSO-like interdecadal variability could be considered as a coupled ocean-atmosphere oscillation, can the interdecadal variability of the Indian monsoon be considered an integral part of the same tropical coupled mode of variability? How does the monsoonENSO relation vary on the interdecadal timescale? Is the physical mechanism for the monsoon-SST relation on the interdecadal timescale different from that on the interannual timescale? The objective of the present study is to obtain some answers to the above questions. In addition to the interdecadal variations of the ENSO and the Indian monsoon described above, other climatic signals in the decadal to multidecadal timescales have been resolved in the Tropics and subtropics (Mann and Park 1993, 1994, 1996; Mann et al. 1995; Gershunov and Barnett 1998). Although these studies show some similarities in the low-frequency signals, they also show some important differences in the spatial patterns of the signals. In the present study, we focus only on the interdecadal oscillations of the ENSO and the Indian monsoon and show that they may be manifestations of the same global oscillation.

The behavior of the interdecadal epochs of the monsoon may have great socioeconomic impact in the South Asian region. For example, with the seasonal [JuneSeptember (JJAS) season] rainfall being above normal on the average, the Indian monsoon has not led to any serious droughts during the last $8 \mathrm{yr}$. Based on the record of IMR from 1871 to 1997 and extrapolating the trend of the interdecadal variability, one may infer that the Indian monsoon is in the beginning of a multidecadal above-normal rainfall phase. However, such a conclusion would be of interest only when stated with certain confidence. Our understanding of the interdecadal variability in the Tropics in general, and the monsoon in particular, is in its very early stages. If it can be established that the interdecadal variability of the Indian monsoon is an integral part of a tropical coupled oceanatmosphere oscillation, it would provide a basis for extended predictability of such epochs. Further, within the framework of a coupled mode, if we can understand the physical mechanism through which ENSO and the Indian monsoon interact, it would add confidence to the potential predictability of the interdecadal monsoon epochs.

The empirical relationship between IMR and ENSO on the interannual timescale has been studied extensively (Sikka 1980; Pant and Parthasarathy 1981; Rasmusson and Carpenter 1983; Shukla and Paolino 1983; Parthasarathy and Pant 1985; Shukla 1987). If we consider the Niño-3 SST anomaly as an index of the ENSO variability, the long-term (based on $127 \mathrm{yr}$ ) correlation between the seasonal anomalies of IMR and Niño-3 SST is -0.63 , significant at $99.9 \%$ level. This correlation represents a tendency of the Indian monsoon to be below normal when the eastern Pacific is warm. However, there are times when the ENSO-related tendency is overcome by other factors (possibly of internal origin) in determining the seasonal mean monsoon. The physical mechanism through which ENSO is related to the monsoon (e.g., the SST variations in the eastern Pacific being negatively correlated with the IMR) has also been addressed by several studies in the recent years (Webster 1987; Webster and Yang 1992; Nigam 1994; Goswami 1998). The interannual variation of the Indian monsoon is characterized by fluctuations of a regional Hadley circulation. A strong monsoon is associated with anomalous ascent around $25^{\circ} \mathrm{N}$ and a weak monsoon is associated with anomalous ascent near the equator (Goswami et al. 1999). ENSO influences the Indian monsoon not by direct subsidence over the Indian continental region but through an interaction between the equatorial Walker circulation and the regional monsoon Hadley circulation. The warm episodes of ENSO are associated with a shift in the climatological Walker circulation to the eastern Pacific. This shift results in enhanced lowlevel convergence over the equatorial Indian Ocean and in driving an anomalous Hadley circulation with descent over the Indian continent and decreased monsoon rainfall (Goswami 1998).

The physical connection between the Indian monsoon and ENSO on the interdecadal timescale has not been adequately addressed so far. Using observations of IMR, Niño-3 SST and solar irradiance at the top of the atmosphere derived from sunspot cycle information for the period 1872-1990, Mehta and Lau (1997) showed that, on the multidecadal timescale, the IMR and solar irradiance vary with nearly the same phase while the Niño-3 SST anomaly varies nearly out of phase with 
the other two. They proposed that increased solar radiation produces a stronger north-south temperature gradient and a stronger monsoon. A stronger monsoon then produces stronger easterlies in the Pacific, and, through local and remote effects of winds, produces surface cooling and negative SST anomalies. While this may be a possible mechanism, it is not clear whether the initial north-south temperature gradient caused by increased solar radiation would persist beyond a few years as the upper Indian Ocean would also warm up due to the persistent enhanced solar heating.

Most studies of interdecadal variability have been confined to surface data as sufficiently long records are available only for those data. Since the Indian monsoonENSO relation involves teleconnections through Walker and Hadley circulations, upper-air data are needed to gain insight into the physical mechanism for monsoonENSO interaction. For this purpose, we use a 49-yr circulation dataset from the National Centers for Environmental Prediction-National Center for Atmospheric Research (NCEP-NCAR) reanalysis products. Although 49 yr may not be long enough for the interdecadal variability, the reanalysis period (1950-98) happens to contain a major transition of the ENSO-like interdecadal mode in the 1970s. Therefore, we expect the reanalysis dataset to provide valuable insight regarding the three-dimensional structure of the interdecadal variability. The paper is organized as follows. Datasets and method of analysis are described in section 2 . In section 3, we discuss the relationship between the monsoon and SST as well as sea level pressure (SLP) on the interdecadal timescale, and also discuss how the interannual monsoon-ENSO relationship is modified on the interdecadal timescale. Section 4 provides the spatial structures of SST and SLP associated with the interdecadal monsoon mode and compares with those associated with the interannual variations of the monsoon. In section 5, we provide a physical mechanism through which the monsoon and ENSO are related on interdecadal as well as interannual timescales by analyzing the NCEP-NCAR reanalysis data and examining the threedimensional structure of the interdecadal variability. The interaction between the interdecadal and interannual variability is described in section 6 and a physical picture is provided to explain why the monsoon-ENSO relation is basically weak. The main conclusions of the study are summarized in section 7 .

\section{Data and method of analysis}

The monsoon variability, represented by the IMR, is based on rainfall observations at 306 land stations uniformly distributed over India (Parthasarathy et al. 1995). The time series published by Parthasarathy et al. (1995) has been updated to cover the period 1871-1997. For long records of SST, we have used the analysis of global SST for the period 1856-1991, created by Kaplan et al. (1997) at the Lamont-Doherty Earth Observatory. This analysis is based on the application of reduced space optimal estimation to the global SST anomalies, where gaps in the data are removed and sampling errors are reduced. For SLP data, we have used the GMSLP2 dataset developed by the Commonwealth Scientific and Industrial Research Organisation (CSIRO), Australia, and the U.K. Meteorological Office (Allan et al. 1996; Basnett and Parker 1997). This dataset consists of gridded monthly SLP covering the period 1871-1995 and has been developed by blending a combination of existing mean SLP analyses with marine and land observations using Laplacian interpolation technique.

The circulation data used in this study are the products of the NCEP-NCAR reanalysis project (see Kalnay et al. 1996 for details) that is based on a frozen state-ofthe-art global data assimilation system that includes a T63 forecast model and a database that is as complete as possible. Due to the fact that the analysis system and the model remain unchanged throughout the analysis period, the reanalyzed data are expected to be devoid of any artificial climate jumps. We obtained monthly mean horizontal winds and vertical velocity at standard pressure levels for the period 1950-98.

Monthly anomalies of the variables were generated by removing the climatological annual cycle from the monthly means. Whereas the SST anomalies are based on the climatological annual cycle of 1951-80, the monthly climatological means of all other variables were computed for the entire period of the respective datasets. We also constructed seasonal anomalies for JJAS and for December-February (DJF) from the monthly anomalies. Because of our focus on the summer monsoon, most of our analysis is based on JJAS seasonal anomalies. To separate the interdecadal variations from the interannual variations, we used an 11-yr running mean as a low-pass filter on all the variables. Since the major interannual variability of the monsoon is associated with the tropical biennial oscillation and the ENSO, this filter effectively eliminates the interannual variations. We adopted the 11-yr running mean as the low-pass filter after comparing it with a 7-yr running mean and a successive application of centered 5-yr and 7 -yr running means. We found that all three filters brought out very similar interdecadal variability of the IMR and Niño-3 indices. The residual time series, after removing the 11-yr running mean from the original time series, is interpreted as the interannual component. This method of separating the interdecadal variations from the interannual variations is similar to the one used by Kachi and Nitta (1997).

To examine the relation between IMR and SST, we used several indices based on area averages of SST over different regions, in a manner similar to ZWB. We used two indices to characterize the ENSO. The SST anomaly averaged over the Niño-3 region is one such index while the other is the Pacific cold tongue index (CT) defined as the SST anomaly averaged over $\left(180^{\circ}-90^{\circ} \mathrm{W}, 10^{\circ} \mathrm{S}-\right.$ $\left.10^{\circ} \mathrm{N}\right)$. An index of the Indian Ocean (IO) is defined as 
the SST anomaly averaged over $\left(50^{\circ}-100^{\circ} \mathrm{E}, 20^{\circ} \mathrm{S}-\right.$ $20^{\circ} \mathrm{N}$ ). The selection of the IO region is based on the observation that the SST variations over the IO region and over the eastern equatorial Pacific (cold tongue region) are of same sign on the interannual timescale. A North Pacific SST index (NP) is also defined as the SST anomaly averaged over $\left(150^{\circ} \mathrm{E}-150^{\circ} \mathrm{W}, 20^{\circ}-45^{\circ} \mathrm{N}\right)$. Another index of the ENSO is a modified form of the Southern Oscillation index (denoted by SOI*) based on surface pressure anomaly. Similar to the definition by ZWB, the SOI* index is defined as the area-averaged SLP anomaly difference between the tropical Pacific from the dateline eastward and the reminder of the tropical oceans (Atlantic, Indian, and western Pacific) in the $\left(20^{\circ} \mathrm{S}-20^{\circ} \mathrm{N}\right)$ belt.

An examination of all the unfiltered time series showed that the SOI* and all the Pacific SST indices (Niño-3, NP, and CT) do not have significant long-term trends. However, the IO index is found to have a significant trend, quite similar to the warming trend of the global mean SST, going from a colder mean during 1860-1920 (approximately) to a warmer mean during 1940-present (approximately). We also found that the global mean warming trend is mainly contributed by the Atlantic and Indian Ocean basins. Therefore, the IO index was calculated by removing the global mean trend from the SST anomalies in the Indian Ocean.

\section{Variability of monsoon, SST, and SLP}

\section{a. Interdecadal variability}

We now examine the interdecadal variability of the Indian summer monsoon and its relationship with similar variability of tropical SST and SLP. The JJAS seasonal anomaly of IMR during 1871-1997 and its 11-yr running mean are shown in Fig. 1a. Similarly, the JJAS seasonal anomaly of Niño-3 SST for the period 18561991 and its 11-yr running mean are shown in Fig. 1b. All the time series in Fig. 1 are normalized by their respective standard deviations. The Indian summer monsoon has two above-normal epochs on the interdecadal timescale, one between 1878 and 1898 and another between 1931 and 1960, consistent with earlier studies (Parthasarathy et al. 1994; Kripalani and Kulkarni 1997). The IMR also has two below-normal epochs, one during 1898-1929 and the other during 196190. It is clear that there is an out-of-phase relation between the interdecadal variation of the Indian monsoon and that of the Niño-3 SST anomaly for most of the entire period. Major transitions in the interdecadal monsoon signal around 1895 and 1930 correspond well with similar transitions in the interdecadal signal of Niño-3 SST. The Niño-3 SST anomaly (SSTA) seems to follow the same interdecadal oscillation of the IMR, except for a short period (1965-75) when the out-of-phase relationship between the two interdecadal oscillations seems to break down. The recent sustained above-normal con- dition in the eastern Pacific is not without its counterpart in the past. During 1900-30, the eastern Pacific equatorial SST anomaly generally tended to be above-normal. The two full oscillations of the interdecadal monsoon mode between 1880 and 1990 indicate a period of about $55 \mathrm{yr}$, although the observational data are not long enough to establish this unambiguously. We also note from Fig. 1a that the positive to negative transitions of the interdecadal monsoon mode around 1898 and 1961 are much faster than the transition from negative to positive phase around 1930. The transition of SST from negative to positive around 1898 is similar to the rapid transition of the IMR around the same time, while the transition of SST from positive to negative around 1930 is slow and similar to that of the IMR around the same time. However, the transition of SST after 1960 is slower before reaching the eventual positive phase of the 1980s and 1990s.

Figure 1 indicates a strong relationship between IMR and Niño-3 SST on the interdecadal timescale. To examine whether such a relation is also evident with other ENSO indices, we present plots of the low-pass filtered time series of IMR and other ENSO indices (as defined in section 2) in Fig. 2. For easy comparison, the signs of Niño-3, CT, and IO indices have been reversed. It is clear that all the indices show a high degree of coherent variability on the interdecadal timescale. The SOI* is out of phase with all other indices during a relatively short period between 1910 and 1925. Assuming that the interdecadal variations of the equatorial Pacific are part of a coupled ocean-atmosphere oscillation similar to that on the interannual timescale, the low-pass filtered Niño-3 and -SOI* may be expected to follow each other. In fact, they do so during 1861-1910 and 192590. We found (plot not shown) that, on the interannual timescale, the two indices are close throughout the entire period. The difference in the interdecadal timescale arises due to a very small but systematic bias in the SLP data during the period 1910-25. The SLP dataset has a bias in the South Pacific prior to 1950 because of limited availability of data in the Southern Hemisphere (T. Basnett 1999, personal communication). The details and relative shortcomings of the dataset are discussed by Basnett and Parker (1997).

The correlations among different low-pass-filtered indices are given in Table 1. The correlation coefficients in Table 1 have been calculated using the data for period 1876-1986 as concurrent data for all the time series are available for this period only. Statistical significance tests have shown that all the correlations given in Table 1 have confidence levels above $99.9 \%$. Therefore, we can conclude with some confidence that the interdecadal variations of the Indian monsoon and those of SST and SLP are parts of a coupled ocean-atmosphere oscillation on that timescale. It is interesting that the Indian Ocean SST seems to vary in phase with the eastern Pacific SST and has a negative influence on the Indian monsoon. The fact that the low-pass-filtered IMR is more strongly 

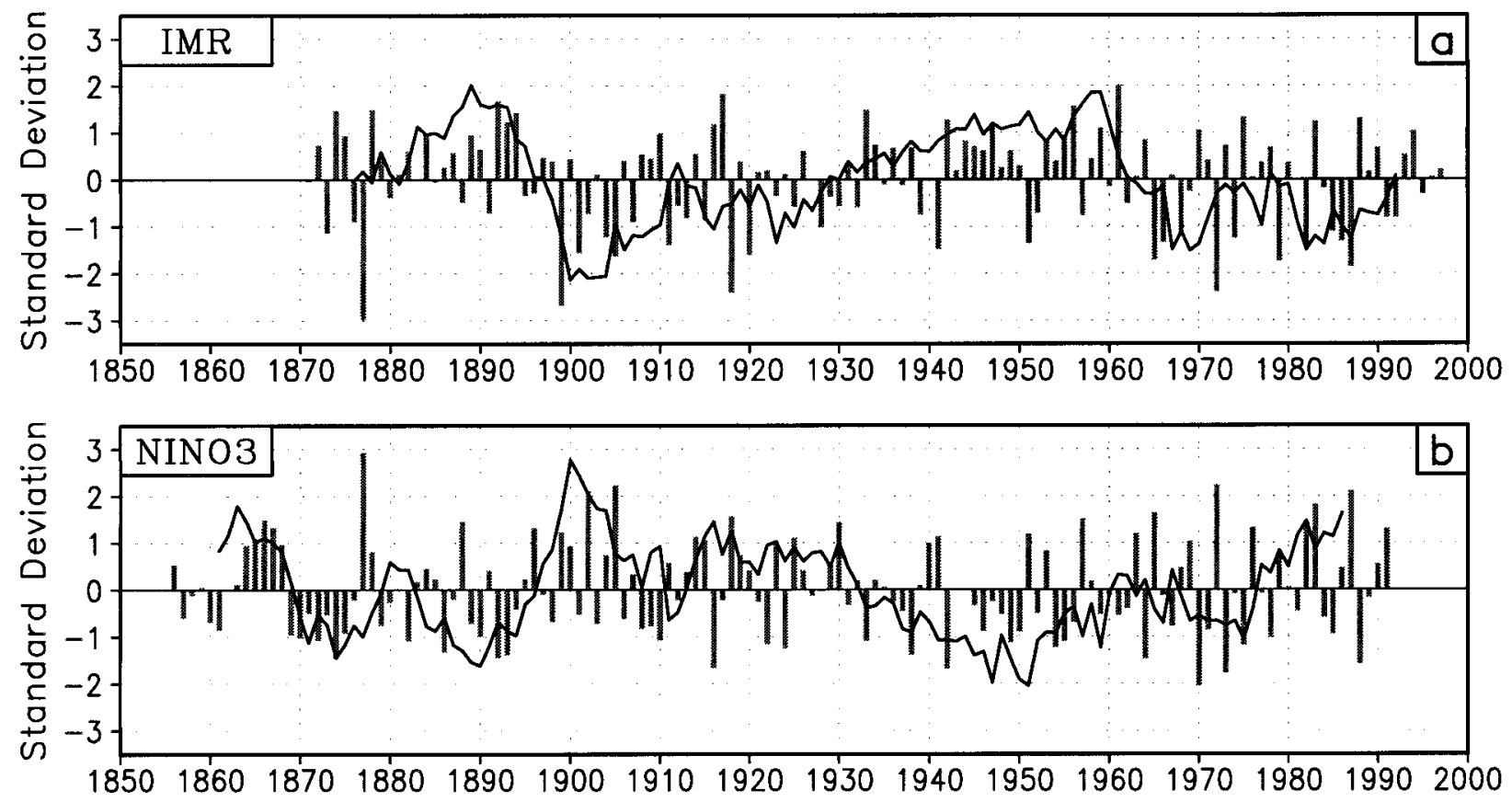

FIG. 1. (a) Time series of JJAS seasonal anomaly of IMR (bar) and its 11-yr running mean (solid line). (b) Same as (a) but for JJAS seasonal anomaly of Niño-3 SST. The time series are plotted in their corresponding standard deviation units. The interannual standard deviation of IMR is $0.66 \mathrm{~mm}_{\text {day }}^{-1}$ while the interdecadal standard deviation is $0.2 \mathrm{~mm}$ day $^{-1}$. For Niño-3, the standard deviations of interannual and interdecadal variations are $0.67 \mathrm{~K}$ and $0.15 \mathrm{~K}$, respectively.

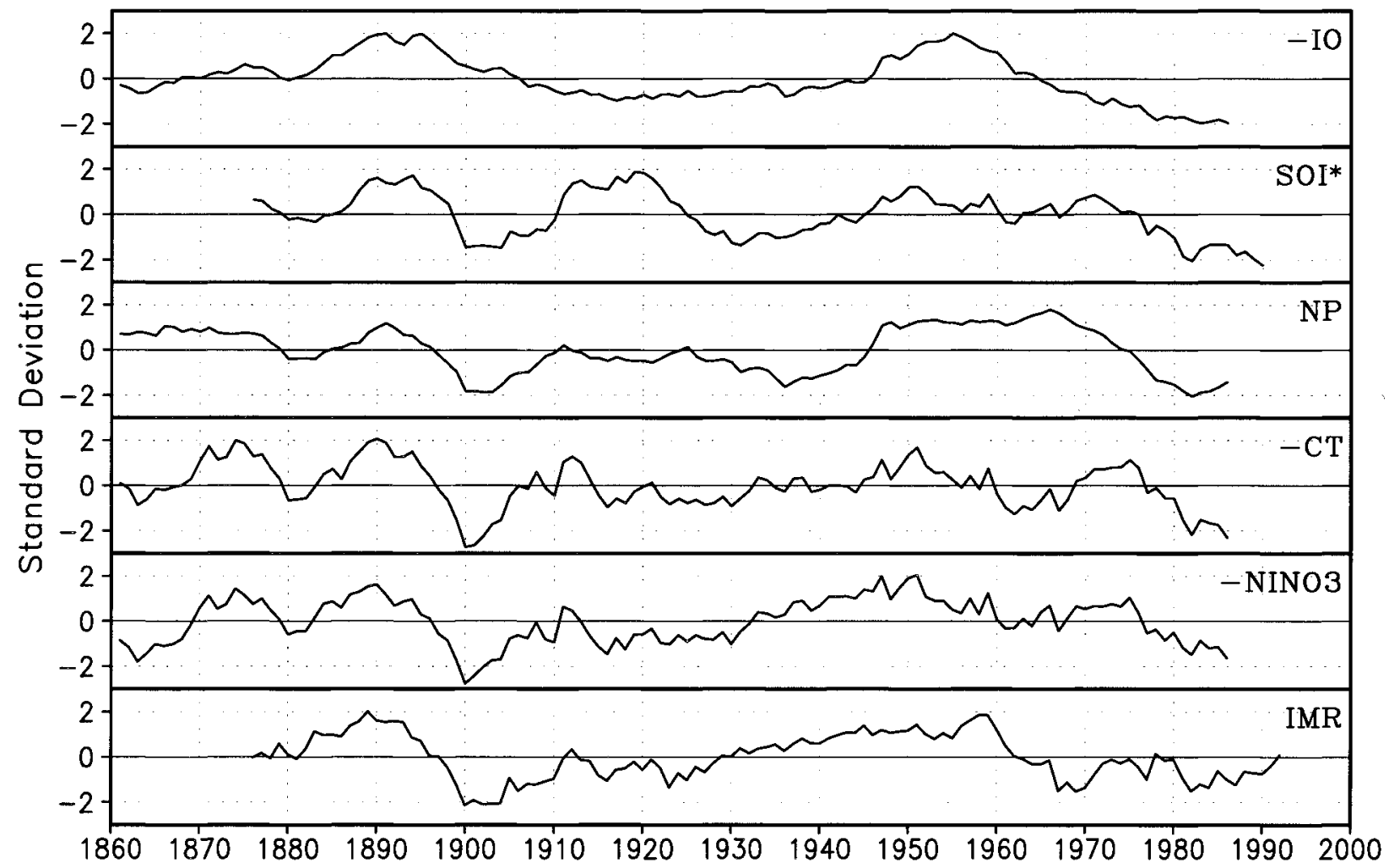

FIG. 2. Time series of low-pass-filtered JJAS seasonal anomalies of IMR, SST, and SLP indices. Signs of Niño-3, CT, and IO are reversed for convenience of comparison. All indices are in standard deviation units. 
TABLE 1. Correlation between various low-pass-filtered indices for the period 1876-1986. The standard deviation of each index is shown within parentheses in the first column. IMR is in $\mathrm{mm} \mathrm{day}^{-1}$, SST indices in $\mathrm{K}$, and $\mathrm{SOI}^{*}$ in $\mathrm{hPa}$. All correlations in this table are significant at $99.9 \%$ level.

\begin{tabular}{lrrrrr}
\hline \hline & IMR & Niño-3 & CT & NP & IO \\
\hline IMR (0.2) & \multicolumn{1}{c}{1.0} & & & & \\
Niño-3 (0.15) & -0.80 & 1.0 & & & \\
CT (0.11) & -0.68 & 0.86 & 1.0 & & \\
NP (0.14) & 0.47 & -0.61 & -0.55 & 1.0 & \\
IO (0.11) & -0.59 & 0.45 & 0.46 & -0.57 & 1.0 \\
SOI* (0.18) & 0.43 & -0.49 & -0.67 & 0.65 & -0.42 \\
\hline
\end{tabular}

correlated with equatorial SST indices (e.g., Niño-3, CT, IO) than with the NP may indicate that the interdecadal monsoon-SST-SLP mode is governed by tropical coupled dynamics much like the ENSO itself. No appreciable lead or lag relation exists between IMR and other indices except for IO (figure not shown).

The interdecadal monsoon-SST mode seen in Fig. 1 does not reveal perfect periodicity, although the length of the observational data is not enough to come to a definite conclusion. However, the approximate timescale of the variability can be estimated to be between 50 and $60 \mathrm{yr}$ based on the available time series of IMR, SST, and SLP (Figs. 1 and 2). If the interdecadal monsoonSST mode is a fundamental oscillation of the tropical climate system, we may expect a similar oscillation to be found in paleoclimate data. Unfortunately, such reliable paleoclimate datasets are very few in number. In a study of one such dataset, based on number of tree ring samples, Pant et al. (1995) reconstructed May-September precipitation at Srinagar (India) going back to 1775 and March-May temperature at Mussoorie (India) going back to 1711 . They showed that both time series revealed interdecadal oscillations, with Mussoorie temperature indicating a period of about 50-60 yr and Srinagar precipitation indicating a somewhat shorter period.

\section{b. Interannual variability}

The residual time series or the interannual variations of all the indices are shown in Fig. 3, and the correlations among them are given in Table 2. The results presented in the correlation table are consistent with previous studies of monsoon-ENSO relationship on the interannual timescale (e.g., Shukla 1987). The amplitude of the Indian Ocean SST on the interannual timescale (as seen from the standard deviation) is very small compared to the ENSO signal. While the interannual standard deviations are about three times larger than the interdecadal standard deviations for IMR and ENSO indices, they are approximately of the same magnitude

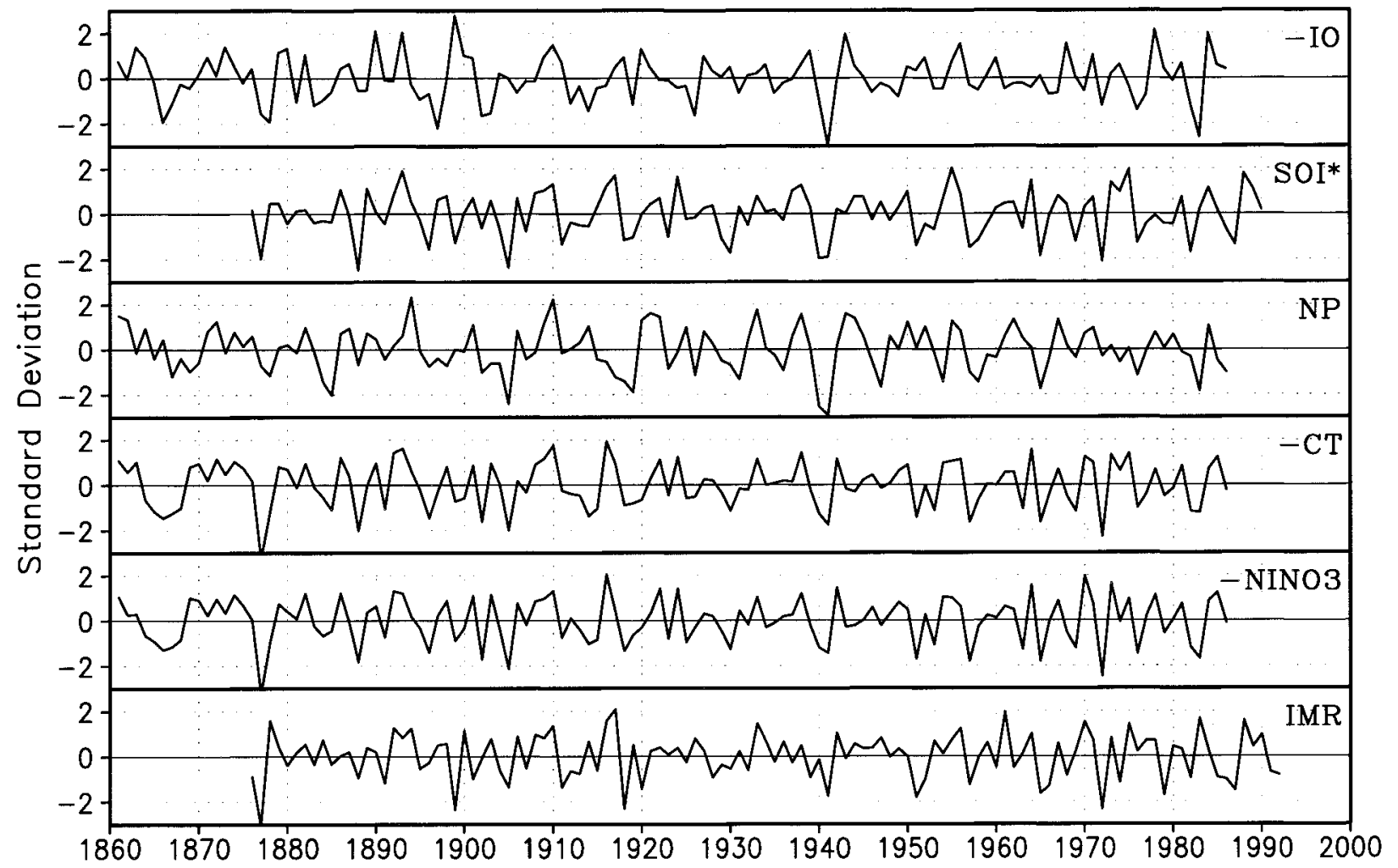

FIG. 3. Same as in Fig. 2 but the time series are residues after removing 11-yr running means from JJAS seasonal anomalies (interannual variations) and standardized. 
TABLE 2. Correlation between various residual (interannual) indices for the period 1876-1986. The standard deviation of each index is shown within parentheses in the first column. IMR is in $\mathrm{mm} \mathrm{day}^{-1}$, SST indices in $\mathrm{K}$ and $\mathrm{SOI}^{*}$ in $\mathrm{hPa}$. Correlations significant at $99.0 \%$ and $99.9 \%$ levels are indicated by one and two asterisks, respectively.

\begin{tabular}{lcrrrr}
\hline \hline & IMR & Niño-3 & CT & NP & IO \\
\hline IMR (0.66) & 1.0 & & & & \\
Niño-3 (0.67) & $-0.59 * *$ & 1.0 & & & \\
CT $(0.49)$ & $-0.58 * *$ & $0.96 * *$ & 1.0 & & \\
NP (0.22) & 0.23 & $-0.49 * *$ & $-0.52 * *$ & 1.0 & \\
IO (0.16) & -0.07 & $0.32 * *$ & $0.41 * *$ & $-0.48 * *$ & 1.0 \\
SOI* $(0.53)$ & $0.62 * *$ & $-0.81 * *$ & $-0.83 * *$ & $0.51 * *$ & $-0.26 *$ \\
\hline
\end{tabular}

for IO. The signs of the correlations between IMR and ENSO indices on the interannual timescale are the same as those on the interdecadal timescale. The interdecadal time series shown in Fig. 2 and their interannual counterparts shown in Fig. 3 are linearly independent as we have found that the correlations between them are close to zero for all the indices. The slight difference in the correlation between IMR and Niño-3 shown in Table 2 and that mentioned in section 1 is due to the fact that the interdecadal signals have been removed from IMR and Niño-3 for the correlations in Table 2 whereas the other correlation is between the unfiltered time series of the seasonal anomalies.

\section{c. Changing interannual variability and monsoon-ENSO relationship}

We now examine whether the changes in the interannual variability and the monsoon-ENSO correlation are in any way related to the interdecadal variability of the monsoon and the ENSO indices. By calculating the variances of the JJAS seasonal anomalies of IMR, Niño-3, and SOI* in an 11-yr moving window, the changes in the interannual variances of monsoon and ENSO are revealed, as shown in Fig. 4. The long-term mean of the 11-yr variance for each index is also shown in Fig. 4. This mean is very close to the variance of the time series of the corresponding index over the entire period. Two important conclusions may be drawn from Fig. 4. First, the interannual variability of monsoon and ENSO indices undergoes slow interdecadal modulations. We note that both IMR and Niño-3 have higher than normal interannual variability during 1895-1925 and during 1960-90, while both have lower than normal interannual variability during $1925-60$. These features correspond almost exactly to the below-normal monsoon (above-normal Niño-3) and above-normal monsoon (below-normal Niño-3) periods of the interdecadal variability shown in Fig. 1. Thus, the interdecadal variability appears to modulate the interannual variability of both monsoon and ENSO. The interannual variance of the SOI* index also shows behavior consistent with IMR and Niño-3 from 1920 onward. However, there are some differences in the variations of SOI* and Niño-3 in the early period. This may be related to the problem
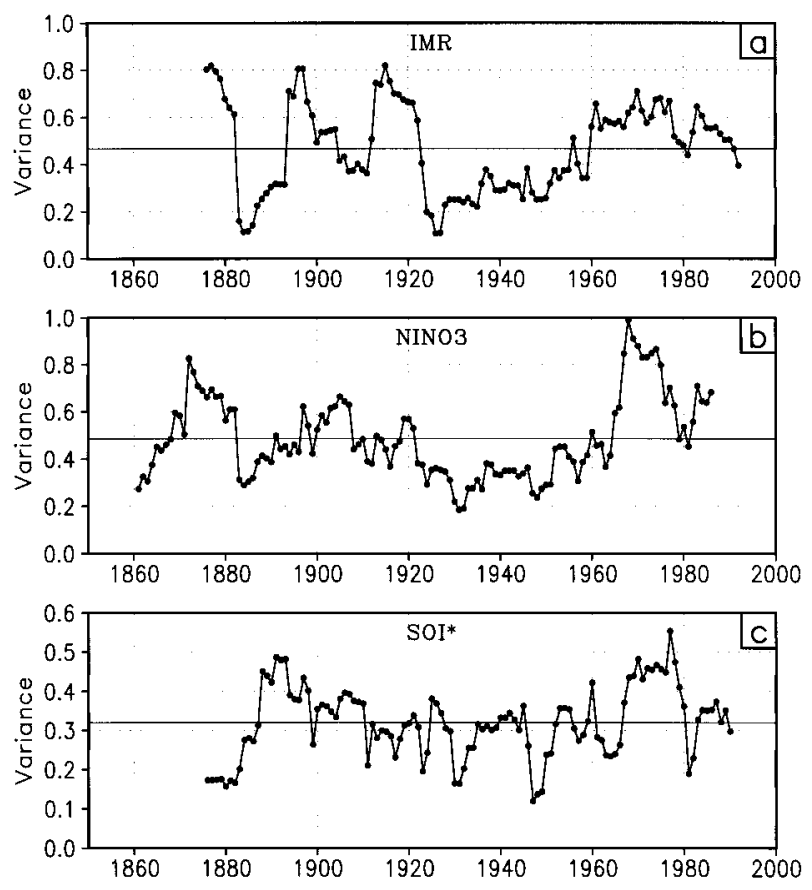

FIG. 4. Variance of JJAS seasonal anomaly of (a) IMR [(mm day $\left.^{-1}\right)^{2}$ ], (b) Niño-3 SSTA $\left(\mathrm{K}^{2}\right)$, and (c) SOI* $\left(\mathrm{hPa}^{2}\right)$ in an 11-yr moving window. The mean of the $11-\mathrm{yr}$ variances over the entire period is shown in a thin straight line for each index.

of the surface pressure data mentioned earlier. Second, the interdecadal variations of both monsoon and ENSO activities are strongly correlated (the correlation coefficient between the two curves in Figs. $4 \mathrm{a}$ and $4 \mathrm{~b}$ is 0.7 ). Thus, the epochs of strong (weak) monsoon activity are also epochs of strong (weak) ENSO activity on the interannual timescale. Both these observations support a hypothesis that the interdecadal variations of the Indian monsoon and tropical SST are part of a tropical coupled ocean-atmosphere oscillation. The general circulation of the ocean-atmosphere system in one phase of the oscillation may facilitate stronger monsoon (floods and/or droughts) and ENSO (El Niño and/or La Niña) variations while the conditions may not be conducive for either monsoon or the ENSO to be strong in the other phase.

The correlations between IMR and ENSO indices (Niño-3 and SOI*) in an 11-yr moving window on the interannual timescale are shown in Fig. 5. The correlations between the monsoon and ENSO clearly undergo low-frequency oscillations. However, the period of these oscillations seems to be close to $15-25 \mathrm{yr}$ rather than the 50-60 yr of the interdecadal oscillation. While the interannual fluctuations of both monsoon and ENSO indices are strongly modulated by the interdecadal mode, the correlations between monsoon and ENSO indices on the interannual timescale are not so strongly modulated by it. This point will be discussed further in section 6 . 

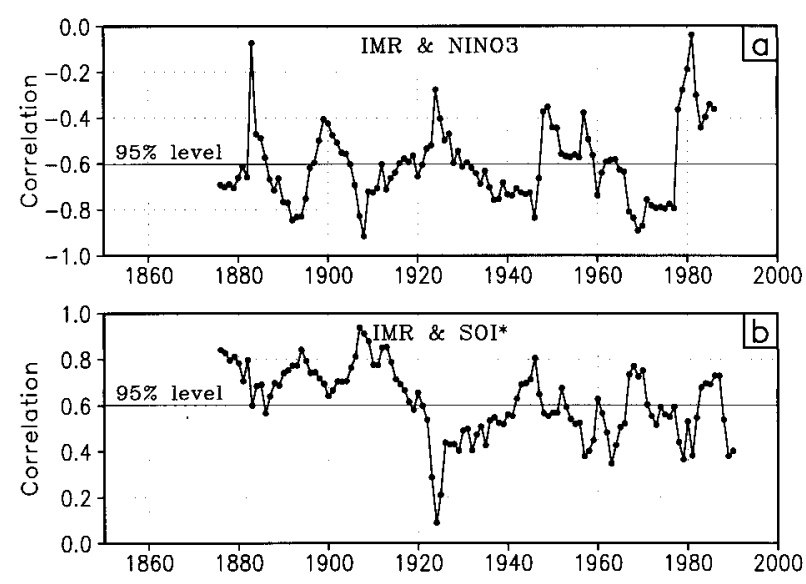

FIG. 5. Correlation between JJAS seasonal anomalies of (a) IMR and Niño-3 SSTA, and (b) IMR and SOI* in an 11-yr moving window. Confidence levels at $95 \%$ are shown in thin straight lines.

\section{Spatial structures associated with the interdecadal monsoon variation}

In this section, we examine the global structures of SST and SLP associated with the interdecadal monsoon mode by regressing these fields upon the low-pass filtered IMR and compare them with the structures of the same fields associated with the interdecadal SST variation. Further comparisons will be made with the regression patterns associated with the interannual monsoon and ENSO variations.

\section{a. Regression patterns of the interdecadal modes}

The spatial patterns obtained by regressing the global SST field upon the low-pass filtered time series of IMR, - Niño-3, NP, and -IO indices are shown in Fig. 6. We note a striking similarity among the four SST patterns shown in Fig. 6, and further observe that the patterns in Fig. 6 are also similar to the ENSO-like interdecadal variability patterns described in earlier studies (e.g., Kachi and Nitta 1997; ZWB). A major north-south dipole pattern in the SST anomaly is present in the Pacific with a broad negative anomaly in the eastern Pacific and a large positive anomaly in the North Pacific centered around $40^{\circ} \mathrm{N}$. The Indian Ocean has a negative anomaly with a center in the south Indian Ocean around $20^{\circ} \mathrm{S}$. The correlation between the patterns associated with IMR and - Niño-3 is 0.88 , and similar correlations of IMR with the patterns of NP and - IO are also high. There are minor differences between the patterns shown in Fig. 6 and the interdecadal pattern shown by ZWB. These differences arise because the patterns in this study represent only the Northern Hemisphere (NH) summer (JJAS) SST anomaly while ZWB regressed the monthly SST data which resulted in more weighting from the $\mathrm{NH}$ winter SST pattern associated with the interdecadal mode.

The spatial patterns obtained by regressing the global

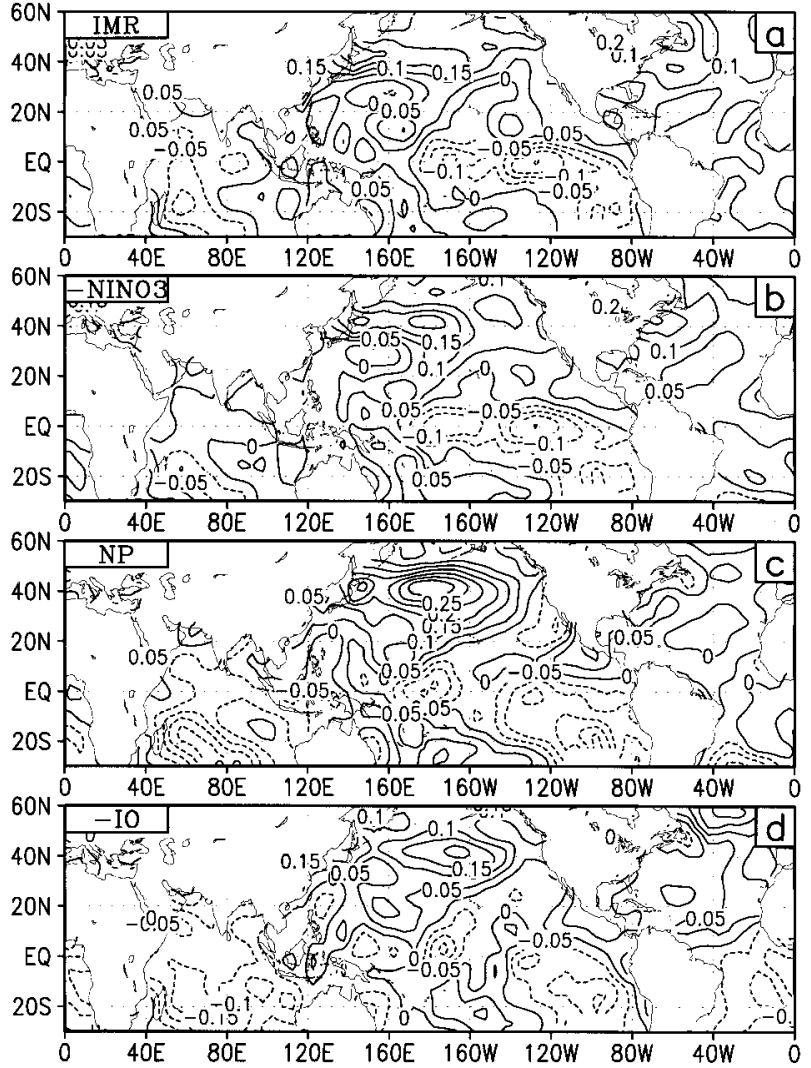

FIG. 6. Spatial patterns obtained by regressing global SST on lowpass-filtered time series (shown in Fig. 2) of (a) IMR, (b) - Niño-3, (c) NP, and (d) - IO. The SST field and the time series are JJAS seasonal anomalies. Negative contours are dashed and contour interval is $0.05 \mathrm{~K}$ per standard deviation of the corresponding time series.

SLP field upon the low-pass filtered time series of IMR, - Niño-3, NP, and - IO indices are shown in Fig. 7. As in the case of SST regression patterns, the SLP patterns associated with the interdecadal variations of all the four indices are also quite similar. The correlation between the SLP patterns associated with the interdecadal IMR and - Niño-3 is 0.89 . The most striking feature in Fig. 7 is the north-south meridional dipole in the Pacific with negative pressure anomaly in the North Pacific and positive pressure anomaly in the southern Tropics. This dipole is associated with anticyclonic circulations in the subtropic of both hemispheres with easterly anomalies in the equatorial Pacific. The patterns in Fig. 7 contrast with the surface pressure pattern associated with the ENSO-like interdecadal variability shown by ZWB (their Fig. 11) because of the fact that ZWB's regression is based on monthly data, which produces an annual average pattern whereas we are examining the summer pattern. This difference indicates that the interdecadal patterns during $\mathrm{NH}$ summer and $\mathrm{NH}$ winter are different. This assertion is substantiated if one examines the difference in the time mean of the SLP anomaly between the two recent epochs, 1977-93 and 1950-76, separately 


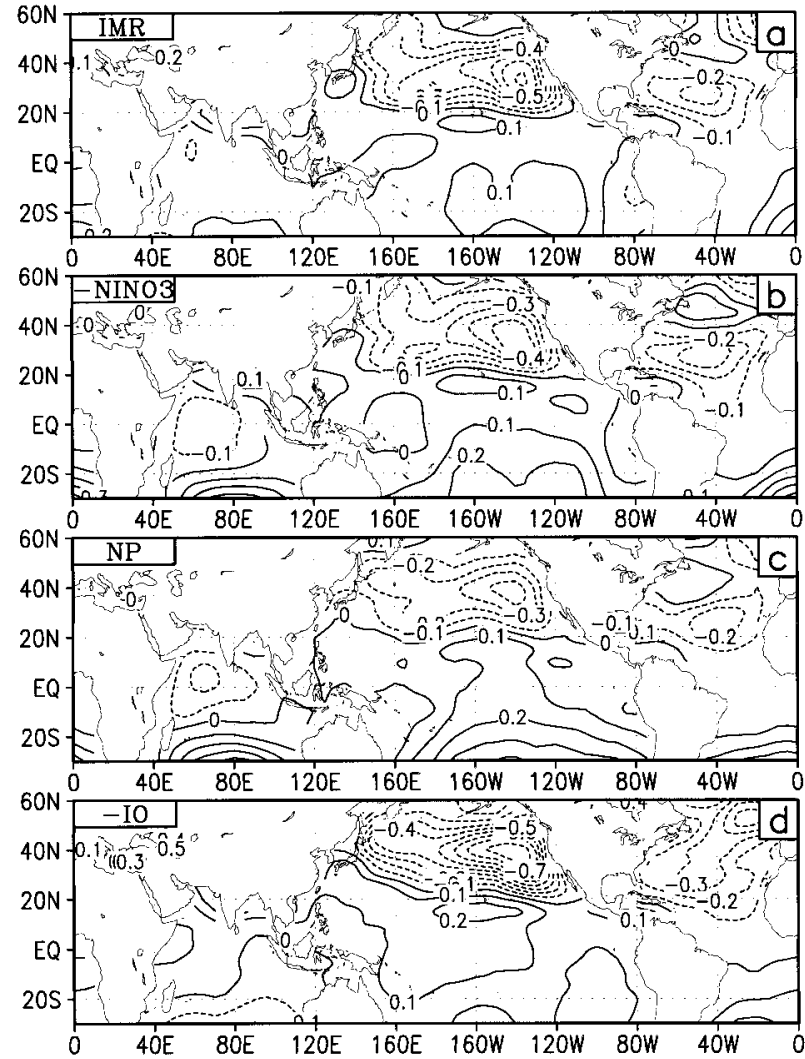

FIG. 7. Same as in Fig. 6 but the regressed field is global SLP Contour interval is $0.1 \mathrm{hPa}$ per standard deviation of the corresponding time series.

for summer (JJAS) and winter (DJF) seasons. Such an examination reveals (figure not shown) that the JJAS anomaly pattern is quite similar to the regression pattern shown in Fig. 7 (with sign reversed because of regression on -Niño-3) with a north-south dipole while the DJF anomaly pattern is similar to the pattern shown by ZWB with the SLP anomalies of the same sign over the entire central Pacific.

\section{b. Comparison between interdecadal and interannual regression patterns}

The spatial structures of the interannual variability in SST and SLP were obtained by regressing these fields upon the residual time series shown in Fig. 3. The spatial patterns of regression of SST on residual IMR, and -Niño-3 are shown in Fig. 8. The pattern associated with the interannual variations of IMR is nearly identical to that with ENSO (Niño-3), and the correlation between the two patterns is 0.95 . This pattern also has strong similarity with that of the interdecadal pattern shown in Fig. 6 except for small differences. In the interannual pattern (Fig. 8), the SST anomalies in the equatorial region are stronger and more confined, whereas those in the North Pacific are weaker. This point was also

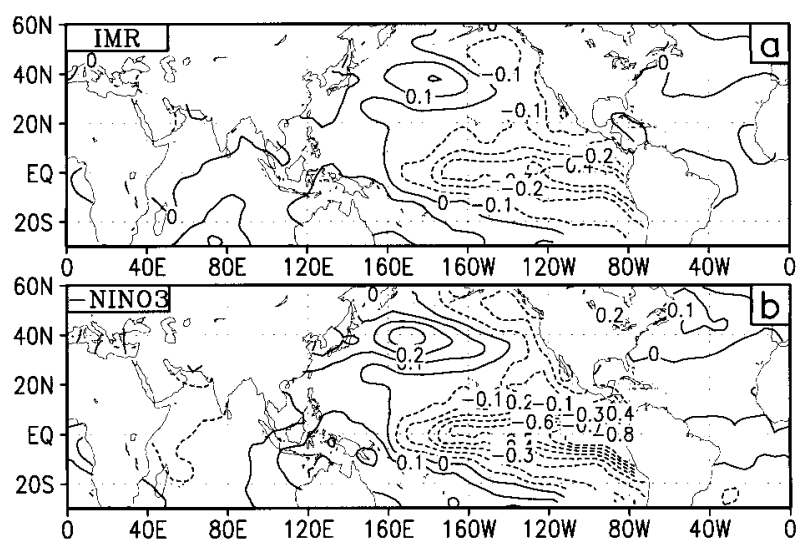

FIG. 8. Spatial patterns obtained by regressing global SST on residual (interannual) time series (shown in Fig. 3) of (a) IMR (b) -Niño-3. The SST field and the time series are JJAS seasonal anomalies. Negative contours are dashed and contour interval is $0.1 \mathrm{~K}$ per standard deviation of the corresponding time series.

noted by ZWB. The interannual pattern associated with a strong Indian monsoon consists of weak negative SST anomalies in the equatorial Indian and Atlantic Oceans and positive anomalies in the equatorial western Pacific. The corresponding regression patterns of SLP are shown in Fig. 9. The spatial patterns of SLP associated with interannual variations of IMR and - Niño-3 are again strikingly similar to one another, the correlation between the two being 0.94. This pattern is similar to the classical Southern Oscillation pattern with SLP of opposite signs between the eastern Pacific and Indian Ocean, and also similar to the interannual pattern obtained by ZWB (their Fig. 12). The eastern half of the Pacific is dominated by SLP anomalies of the same sign extending to the North Pacific with a minimum in the equatorial region. We note that the SLP pattern of the interdecadal variability (Fig. 7) is different from its interannual counterpart (Fig. 9) in the North Pacific. However, over the equatorial and southern Pacific, the SLP associated with

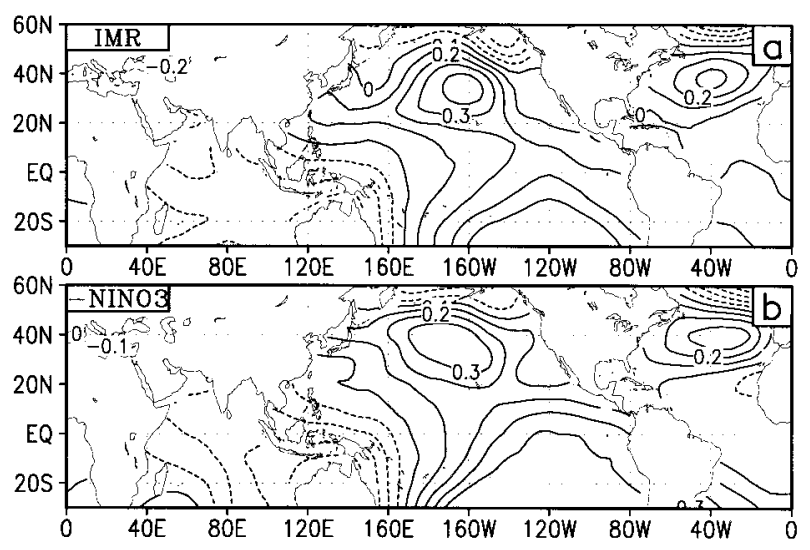

FIG. 9. Same as in Fig. 8 but the regressed field is global SLP. Contour interval is $0.1 \mathrm{hPa}$ per standard deviation of the corresponding time series. 
both the interdecadal and interannual variability is similar.

From the preceding analysis, it is clear that the structure of the interdecadal variability associated with the Indian monsoon is remarkably similar to that associated with the ENSO-like interdecadal variability in the Pacific discussed in earlier studies. Thus, the interdecadal oscillations of monsoon and tropical SST (and SLP) seem to be part of a global coupled ocean-atmosphere oscillation or mode. It has already been shown (ZWB) that the structures of the interdecadal variability of SST and SLP and the interannual ENSO variability are very similar. We have also seen that the structure of the interdecadal monsoon variability is similar to the interannual counterpart. The interdecadal variability of the monsoon is more strongly related to the interdecadal variability in other tropical indices (e.g., Niño-3) than with that of the extratropical index, NP.

\section{c. EOF analysis of the global SST anomalies}

To examine how the patterns of the interdecadal monsoon-SST mode or the interannual monsoon-ENSO mode obtained by the regression analysis are related to the dominant mode of the global SST variability, we conducted an empirical orthogonal function (EOF) analysis of the JJAS seasonal anomaly of detrended global SST. As discussed by ZWB and as explained in section 2 , there is a global warming trend in the SST. An EOF analysis of the SST without removing the trend would show the leading mode to be dominated by the trend. The mathematical constraint that the subsequent principal components (PCs) be orthogonal to this trend makes the physical interpretation of the other modes difficult. Like ZWB, we detrended the monthly SST anomalies at each grid point by subtracting the globally averaged SST anomaly for that month. An EOF analysis was carried out with the seasonal (JJAS) SST anomalies for the period 1856-1991. The first EOF and the corresponding PC are shown in Fig. 10. Due to the similarity between the patterns of interannual and interdecadal variability of the SST (as discussed in the previous section), it is not surprising that the dominant mode essentially brings out the common pattern associated with both the modes of variability. The time series of the 11-yr mean of the first PC (PC1), also plotted in Fig. 10, clearly shows that the interdecadal variability of the dominant SST mode is similar to that of Niño-3 or IMR (Fig. 2). It is clear that PC1 contains both interannual and interdecadal variability. The correlation between the low-pass-filtered PC1 and low-pass filtered Niño-3 is 0.86 , while that between residual PC1 and residual Niño-3 is 0.92 . The correlation between lowpass-filtered PC1 and low-pass-filtered IMR is -0.69 while that between residual PC1 and residual IMR is -0.54 . Thus, the dominant SST mode seems to be an integral part of the monsoon-SST modes in both interdecadal and interannual timescales. (a) EOF 1

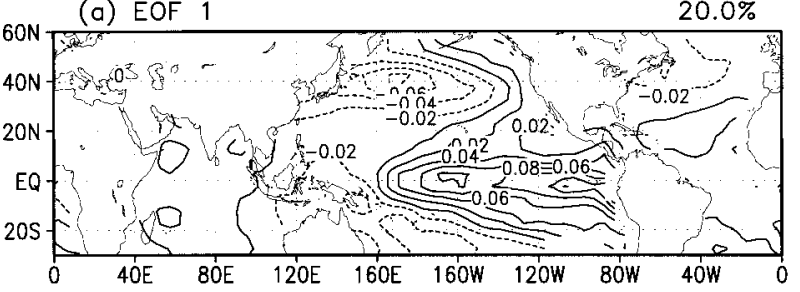

(b) $\mathrm{PC} 1$

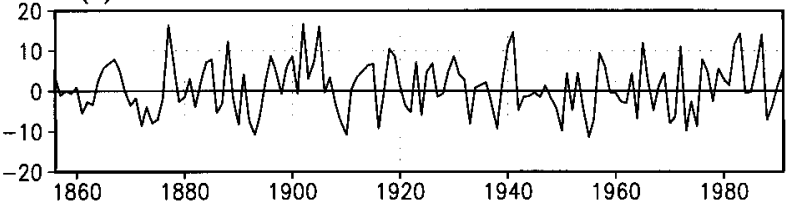

(c) 11-year running mean of $\mathrm{PC} 1$

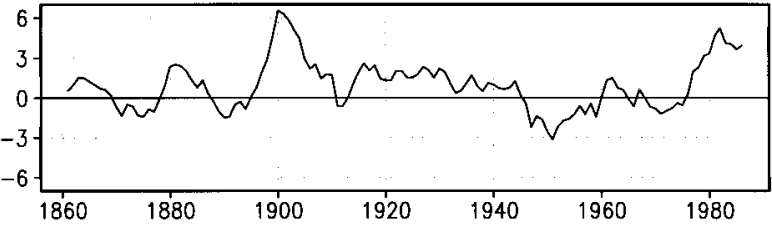

FIG. 10. (a) First EOF and (b) corresponding PC of JJAS seasonal anomaly of SST, and (c) 11-yr running mean of the PC. Units are arbitrary.

\section{Physical mechanisms in Indian monsoon-ENSO relation}

In this section, we examine the 49-yr dataset of the NCEP-NCAR reanalysis to gain insight into the threedimensional structure of the interdecadal monsoon-SST mode and to understand how the monsoon and SST are linked on this timescale. The linkage on the interdecadal timescale will be compared with a similar linkage between the Indian monsoon and ENSO on the interannual timescale in order to understand why there are more floods (droughts) in India associated with the cold (warm) eastern Pacific phases of the interdecadal SST variability. As mentioned in section 1, the Pacific SST and the Indian monsoon are linked through an interaction between the regional monsoon Hadley circulation and the equatorial Walker circulation, whether it is on the interdecadal or the interannual timescale. Although there have been several studies of the ENSO-like interdecadal variability, no study, to our knowledge, has documented the three-dimensional structure of the mode.

\section{a. Monsoon-SST relation on interdecadal timescale}

We now investigate the structures of the Walker circulation and the monsoon Hadley circulation associated with the interdecadal mode. The regressions of the horizontal wind $(U, V)$ and negative pressure vertical velocity $(-\omega)$ on the low-pass-filtered IMR and - Niño-3 at 11 standard pressure levels between $1000 \mathrm{hPa}$ and $100 \mathrm{hPa}$ were calculated. The structure of the Walker circulation was then obtained by averaging the regres- 

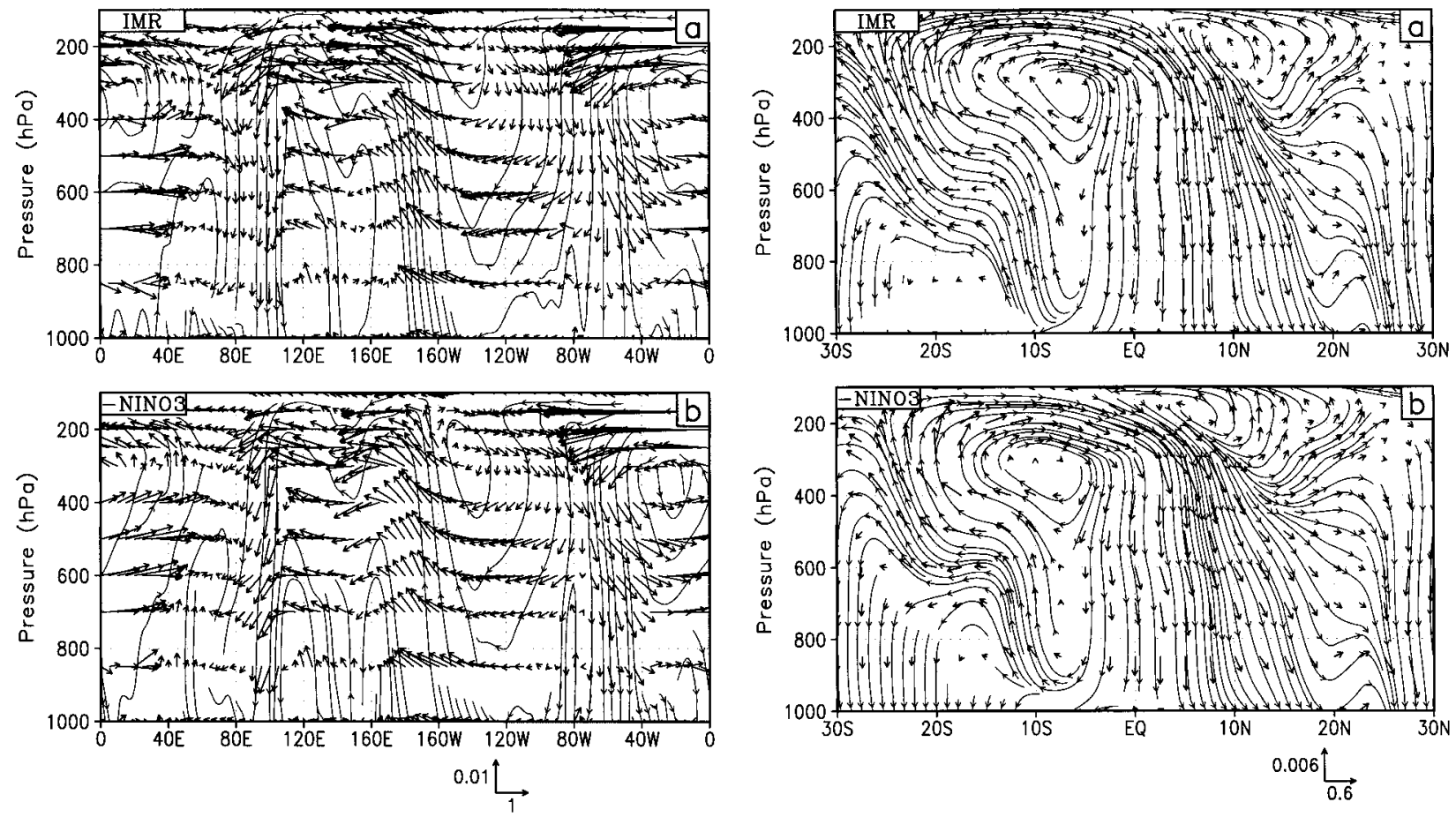

FIG. 11. Walker circulation associated with the interdecadal monsoon and SST variability. Longitude-height section, averaged over $10^{\circ} \mathrm{S}-10^{\circ} \mathrm{N}$, of regression of zonal wind and negative pressure vertical velocity $(U,-\omega)$ on low-pass filtered time series of (a) IMR and (b) -Niño-3 indices. All regressed fields and indices are JJAS seasonal anomalies. Unit vector in the horizontal direction is $1 \mathrm{~m} \mathrm{~s}^{-1}$ (standard deviation $)^{-1}$ while that in the vertical direction is $0.01 \mathrm{~Pa} \mathrm{~s}^{-1}$ (standard deviation $)^{-1}$. Streamlines are shown in thin lines.

sions between $10^{\circ} \mathrm{S}$ and $10^{\circ} \mathrm{N}$. The height-longitude sections depicting the Walker circulation associated with the interdecadal monsoon and Niño-3 oscillations are shown in Fig. 11. We note that the Walker circulation associated with the interdecadal IMR and Niño-3 modes are similar to each other, supporting our earlier conclusion that they are essentially the same mode. The Walker circulation is characterized by a wavenumber two structure in the east-west direction. Associated with a positive phase of the interdecadal monsoon oscillation, there is ascending motion around the dateline and descending motion over the Indian Ocean centered around $95^{\circ} \mathrm{E}$ and over South America centered around $60^{\circ} \mathrm{W}$. The descending motion around $60^{\circ} \mathrm{W}$ forms a third cell along with the ascending motion in east Africa centered around $40^{\circ} \mathrm{E}$. A narrow fourth cell is formed by the descending motion over the equatorial Indian Ocean and the ascending motion over eastern Africa.

The structure of the monsoon Hadley circulation was obtained by averaging the regressions between $70^{\circ} \mathrm{E}$ and $120^{\circ} \mathrm{E}$. The height-latitude sections in Fig. 12 depict the monsoon Hadley circulation associated with the interdecadal monsoon and Niño-3 variations. The monsoon Hadley circulation associated with the positive phase of the interdecadal monsoon oscillation (or the

FIG. 12. Regional Hadley circulation associated with the interdecadal monsoon and SST variability. Latitude-height section, averaged over $70^{\circ}-120^{\circ} \mathrm{E}$, of regression of meridional wind and negative pressure vertical velocity $(V,-\omega)$ on low-pass-filtered time series of (a) IMR and (b) - Niño-3 indices. All regressed fields and indices are JJAS seasonal anomalies. Unit vector in the horizontal direction is $0.6 \mathrm{~m} \mathrm{~s}^{-1}$ (standard deviation) $)^{-1}$ while that in the vertical direction is $0.006 \mathrm{~Pa} \mathrm{~s}^{-1}$ (standard deviation) $)^{-1}$. Streamlines are shown in thin lines.

negative phase of Niño-3) is characterized by two anomalous meridional circulations with descending motion around the equator and ascending motion around $20^{\circ} \mathrm{N}$ and $15^{\circ} \mathrm{S}$, respectively. While the anomalous Hadley cell in the Southern Hemisphere (SH) is deep, extending to the surface, the cell in the $\mathrm{NH}$ is confined above 500 $\mathrm{hPa}$. The ascending motion around $20^{\circ} \mathrm{N}$ is less pronounced in the middle levels but more evident in lower and upper levels. The descending motion around the equator extends up to $15^{\circ} \mathrm{N}$ making the southern Hadley cell larger in meridional extent than the northern Hadley cell. Thus, the Walker and the Hadley circulations have common descending motion over the equatorial Indian Ocean, suppressing the equatorial tropical convergence zone (TCZ) and facilitating the continental TCZ to thrive. The ascending motion over the monsoon continent around $20^{\circ} \mathrm{N}$ of the Hadley mode is also associated with relatively strong descending motion in the subHimalayan region between $25^{\circ} \mathrm{N}$ and $35^{\circ} \mathrm{N}$.

\section{b. Monsoon-SST relation on interannual timescale}

The structures of the Walker and monsoon Hadley circulations associated with the interannual variability are discussed in this subsection. As in the previous sub- 

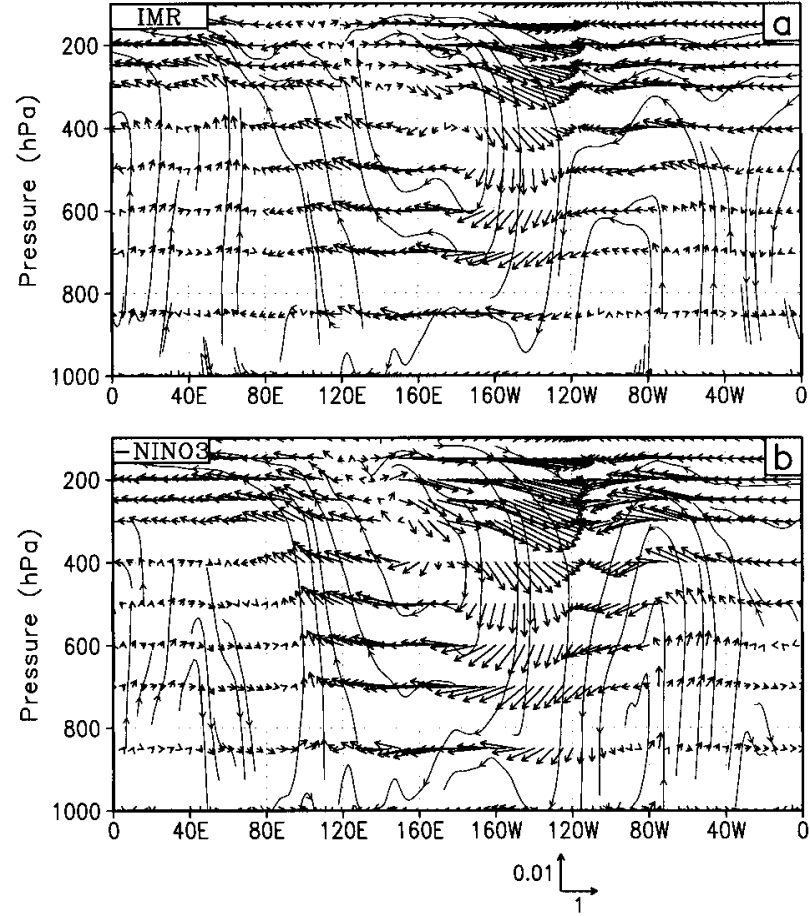

Fig. 13. Walker circulation associated with the interannual monsoon and SST variability. Longitude-height section, averaged over $10^{\circ} \mathrm{S}-10^{\circ} \mathrm{N}$, of regression of zonal wind and negative pressure vertical velocity $(U,-\omega)$ on residual time series of (a) IMR and (b) - Niño-3 indices. All regressed fields and indices are JJAS seasonal anomalies. Unit vector in the horizontal direction is $1 \mathrm{~m} \mathrm{~s}^{-1}$ (standard deviation) ${ }^{-1}$ while that in the vertical direction is $0.01 \mathrm{~Pa} \mathrm{~s}^{-1}$ (standard deviation $)^{-1}$. Streamlines are shown in thin lines.

section, regressions of $U, V$, and $-\omega$ on the residual (or interannual) IMR and -Niño-3 at 11 standard pressure levels between $1000 \mathrm{hPa}$ and $100 \mathrm{hPa}$ were calculated. The height-longitude sections depicting the Walker circulation associated with the interannual monsoon and SST variations are shown in Fig. 13. The Walker circulations associated with the interannual IMR (Fig. 13a) and Niño-3 SST variations (Fig. 13b) closely resemble each other, except for very small differences in the regions $80^{\circ} \mathrm{W}-0^{\circ}$ and $40^{\circ}-60^{\circ} \mathrm{E}$ at lower levels. The Walker circulation associated with a strong monsoon (La Niña) is dominated by a strong anomalous east-west cell with descending motion in the eastern Pacific centered around $140^{\circ} \mathrm{W}$ and ascending motion in the western Pacific centered around $130^{\circ} \mathrm{E}$. On either side of this cell there are two weaker cells, one with ascending motion over South America centered around $60^{\circ} \mathrm{W}$ and another with descending motion over the equatorial Indian Ocean centered around $80^{\circ} \mathrm{E}$. Additionally, there are two weak cells over the Atlantic and Africa. This picture would be reversed during a drought phase of Indian monsoon or during an El Niño.

The height-latitude sections depicting the monsoon Hadley circulation are shown in Fig. 14. The monsoon Hadley circulation associated with the positive phase of
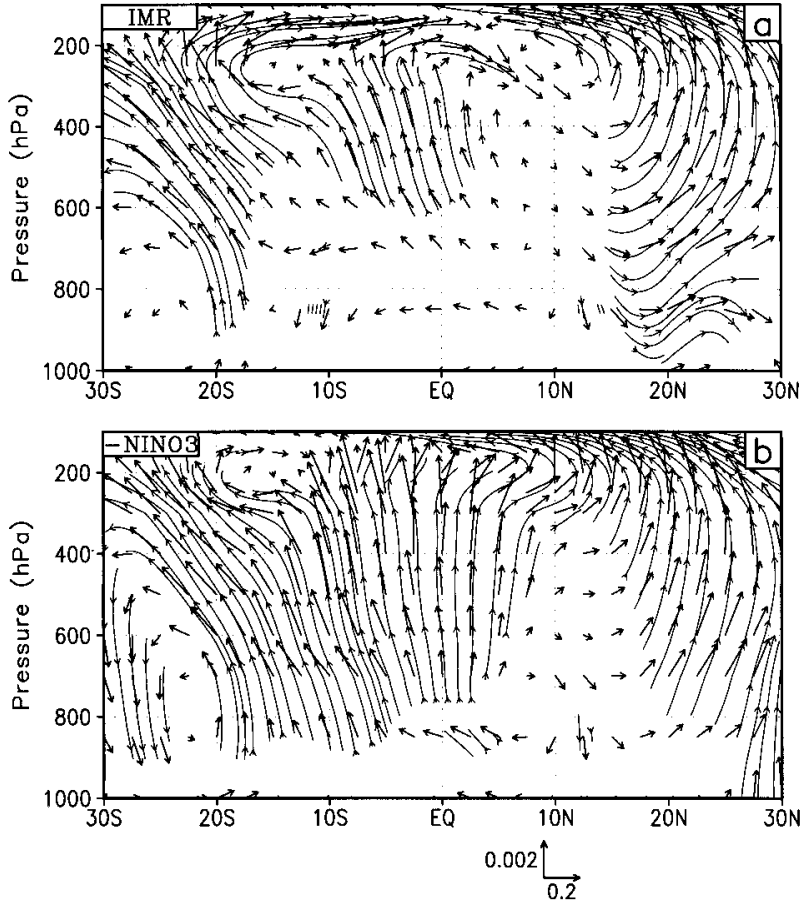

FIG. 14. Regional Hadley circulation associated with the interannual monsoon and SST variability. Latitude-height section, averaged over $70^{\circ}-120^{\circ} \mathrm{E}$, of regression of meridional wind and negative pressure vertical velocity $(V,-\omega)$ on residual time series of (a) IMR and (b) -Niño-3 indices. All regressed fields and indices are JJAS seasonal anomalies. Unit vector in the horizontal direction is $0.2 \mathrm{~m} \mathrm{~s}^{-1}$ (standard deviation $)^{-1}$ while that in the vertical direction is $0.002 \mathrm{~Pa}$ $\mathrm{s}^{-1}$ (standard deviation) $)^{-1}$. Streamlines are shown in thin lines.

the interannual monsoon variation (or the negative phase of Niño-3) is characterized by two anomalous meridional circulations with descending motion between $5^{\circ} \mathrm{N}$ and $15^{\circ} \mathrm{N}$ and ascending motion around $25^{\circ} \mathrm{N}$ and $0^{\circ}-$ $20^{\circ} \mathrm{S}$, respectively. The descending motion near the equator is rather weak and confined to the lower atmosphere compared to the strong and deep descending motion in the north and south. There are minor differences between the Hadley circulation anomalies associated with IMR (Fig. 14a) and those associated with Niño-3 (Fig. 14b) in the equatorial upper atmosphere. The two anomalous regional Hadley cells brought out by the regression analysis are characteristic of the interannual monsoon variability, as shown in a recent study (Goswami et al. 1999). Taking the standard deviations of the IMR and Niño-3 time series into consideration, the regression patterns (Figs. 12 and 14) indicate that the strengths of the anomalous Hadley circulations associated with the interannual and interdecadal variations are comparable. A better picture of the strengths of these Hadley circulations can be obtained from the composite Hadley anomalies. The strength of the anomalous interdecadal Hadley circulation is shown in Fig. 15a as the difference between composites of lowpass filtered winds from cold and warm periods of the 

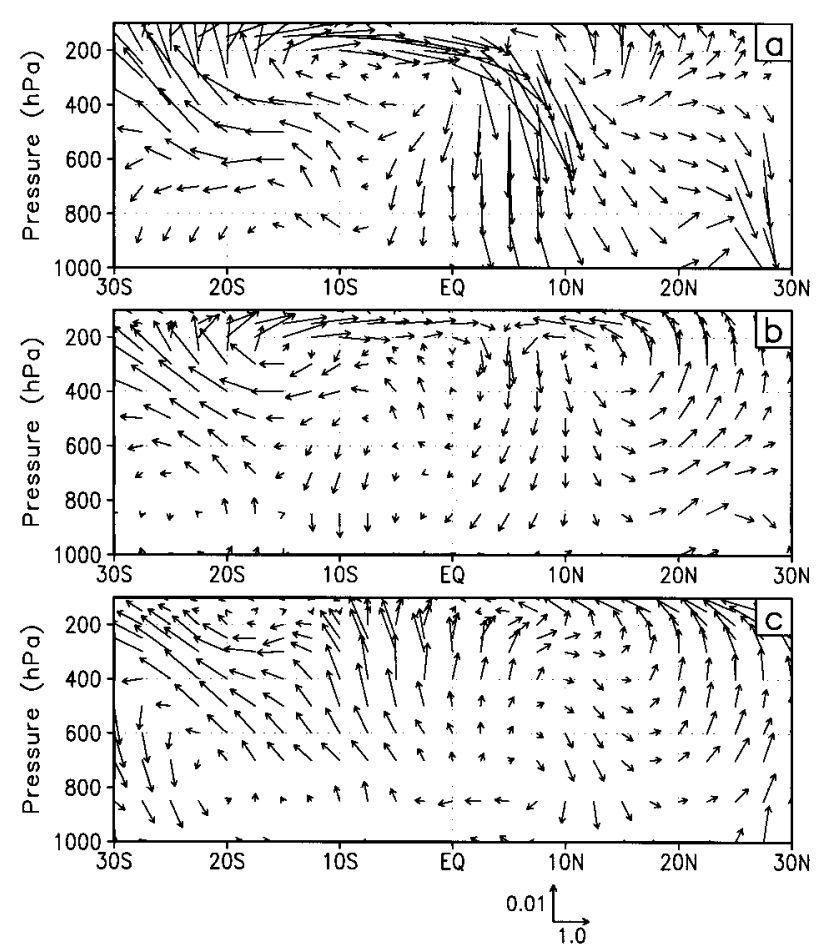

FIG. 15. Composite regional Hadley circulation: latitude-height section, averaged over $70^{\circ}-120^{\circ} \mathrm{E}$, of meridional wind and negative pressure vertical velocity $(V,-\omega)$. Difference between composites of (a) low-pass filtered winds for cold (1956-60) and warm (198690) periods of the interdecadal SST variation, (b) residual winds for five strong and five weak monsoon years, and (c) residual winds for five La Niña and five El Niño years. Unit vector in the horizontal direction is $1.0 \mathrm{~m} \mathrm{~s}^{-1}$ while that in the vertical direction is $0.01 \mathrm{~Pa}$ $\mathrm{s}^{-1}$.

interdecadal SST variation. Similarly, the strength of the interannual Hadley circulation is shown in Figs. 15b and $15 \mathrm{c}$ as the difference in the composites of residual winds between strong and weak monsoon years and between La Niña and El Niño years, respectively. Figure 15 indicates that the strengths of the regional Hadley circulations associated with the interdecadal and interannual modes are quite comparable. The structures of the Hadley circulation composites in Fig. 15 are also similar to the corresponding regression patterns in Figs. 12 and 14. As with the interdecadal mode, both the Walker and Hadley circulations associated with the interannual mode have descending motion over the equatorial Indian Ocean suppressing the equatorial TCZ.

\section{c. Three-dimensional structure of the interdecadal mode}

In section $5 \mathrm{a}$, we derived the three-dimensional structure of the circulation associated with the interdecadal variability using regression analysis. Here, we present the three-dimensional structure of the interdecadal circulation mode using an independent analysis and compare it with the regression pattern. Since we are mainly concerned with the NH summer in this study, we consider only the JJAS circulation anomalies for all 49 years. The interdecadal components of the circulation anomalies were separated using the same low-pass filter (11-yr running mean) as before. We performed a combined EOF analysis of the low-pass filtered winds $(U$, $V, \omega)$ at $850 \mathrm{hPa}, 500 \mathrm{hPa}$, and $200 \mathrm{hPa}$. The spatial patterns of the first EOF are shown in Fig. 16, and the corresponding patterns obtained by regressing the wind fields on the low-pass-filtered Niño-3 index are shown in Fig. 17 for comparison. The first PC (not shown) confirms that this mode indeed represents the major interdecadal component with a transition in the 1970s. The wind structure in the lower and upper atmosphere indicates a first baroclinic mode structure in the vertical. The striking similarity between the patterns obtained through the two independent analyses indicates that the three-dimensional structure obtained by the regression analysis represents the true structure associated with the interdecadal variation.

\section{Relationship between interannual and interdecadal variability of circulation}

The analysis of the previous section indicates that there are some differences in the Walker circulation associated with the interdecadal and the interannual variations. However, both circulation modes consist of descending (ascending) motion over the equatorial Indian Ocean associated with strong (weak) phases of the monsoon. There are also some differences in the monsoon Hadley circulation associated with the interdecadal and interannual modes. The descending motion, between the equator and $15^{\circ} \mathrm{N}$, associated with the positive phase of the interdecadal monsoon mode is quite strong relative to the corresponding ascending motion in the north and south (Fig. 12a). The descending motion associated with the interannual counterpart is weak relative to the corresponding ascending motion in the north and south (Fig. 14a). However, within $25^{\circ} \mathrm{S}-20^{\circ} \mathrm{N}$, the strong (weak) phases of both the modes consist of two anomalous Hadley cells with descending (ascending) motion in the equatorial Indian Ocean region and ascending (descending) motion over the Indian continent $\left(15^{\circ}-\right.$ $\left.25^{\circ} \mathrm{N}\right)$ and over the $\mathrm{SH}\left(10^{\circ}-25^{\circ} \mathrm{S}\right)$.

Based on the similarities in the monsoon Hadley circulation anomalies (and also in Walker circulation anomalies over the equatorial Indian Ocean) associated with the interdecadal and interannual variations, a conceptual picture of the interaction between monsoon and ENSO may be constructed. We recall that the strength of the Indian monsoon depends on the strength of the regional monsoon Hadley circulation. Within a particular phase of the interdecadal oscillation there could be several strong and weak phases of the interannual variations. During a warm phase of the interdecadal SST variation, the decrease in the monsoon rainfall is associated with the anomalous ascending motion in the 


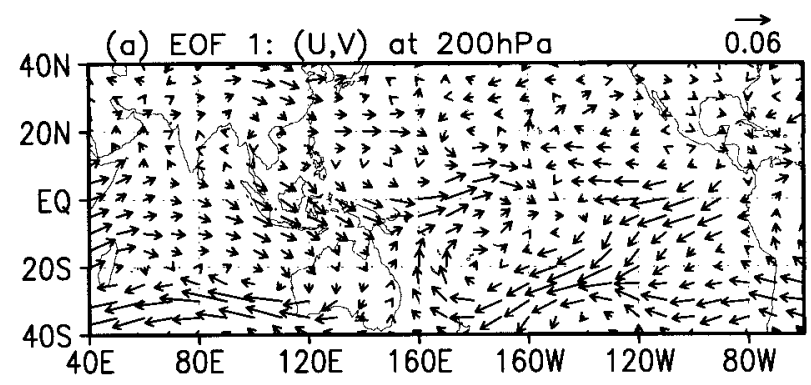

(b) EOF 1: $\omega$ at $500 \mathrm{hPa}$
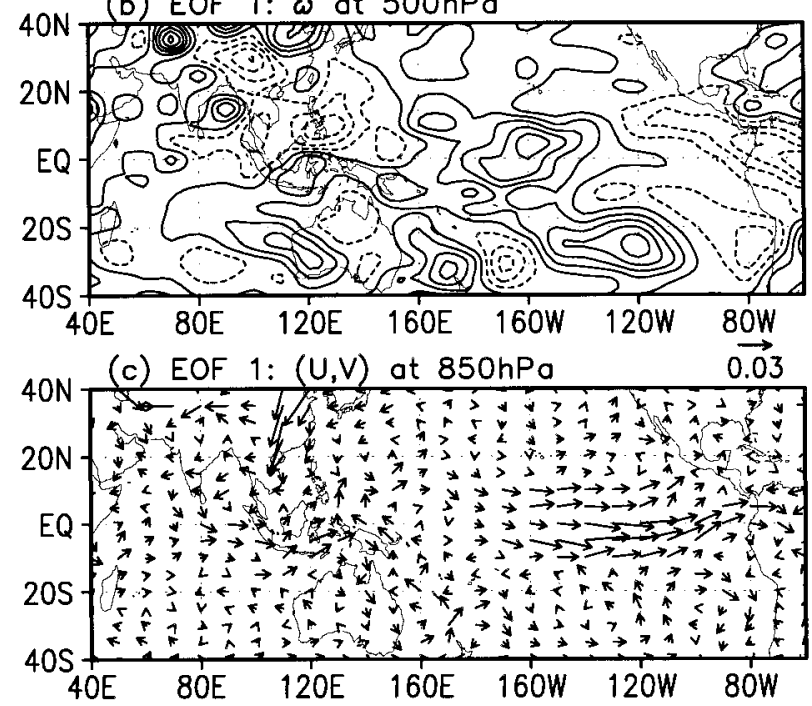

FIG. 16. Spatial patterns of (a) horizontal wind $(U, V)$ at $200 \mathrm{hPa}$; (b) pressure vertical velocity, $\omega$, at $500 \mathrm{hPa}$; and (c) horizontal wind $(U, V)$ at $850 \mathrm{hPa}$ associated with the dominant mode of a combined EOF analysis of low-pass filtered JJAS seasonal anomalies of all the fields shown. Units of EOF are arbitrary.

equatorial Indian Ocean and descending motion over the Indian continent (through the modification of the Walker circulation that also influences the regional Hadley circulation), just the same way it happens during an El Niño episode on the interannual timescale. The two modes being linearly independent, the monsoon variations would be determined by a superposition of the interdecadal and interannual anomalies.

Figure 18 schematically illustrates how the interaction between the interdecadal and interannual variations of the SST is associated with the monsoon variability, keeping in mind the discussion related to Fig. 15 presented in section 5b. The illustration is limited to what happens in two interannual extremes (El Niño and La Niña) when the interdecadal SST mode is in the positive phase of eastern Pacific SST, and therefore when the interdecadal Hadley and Walker circulations remain the same. In an El Niño episode within this interdecadal phase, the interannual regional Hadley and Walker circulations are in phase with the interdecadal variations, thus further weakening the monsoon circulation and enhancing the possibility of significantly decreased rainfall over the Indian continent. On the other hand, the in-
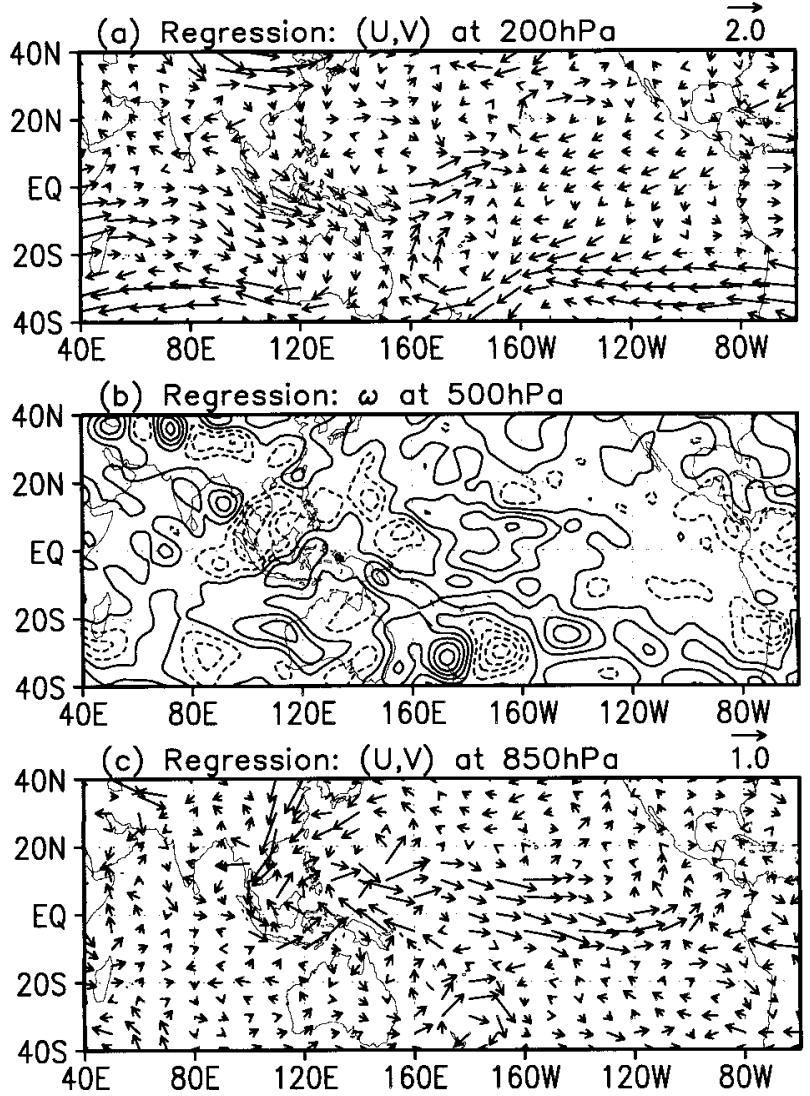

FIG. 17. Spatial patterns obtained by regressing (a) horizontal wind $(U, V)$ at $200 \mathrm{hPa}$; (b) pressure vertical velocity, $\omega$, at $500 \mathrm{hPa}$; and (c) horizontal wind $(U, V)$ at $850 \mathrm{hPa}$ upon low-pass-filtered time series of Niño-3 index. All regressed fields and Niño-3 index are JJAS seasonal anomalies. Unit vectors in (a) and (c) are 2.0 and 1.0 $\mathrm{m} \mathrm{s}^{-1}$ (standard deviation) ${ }^{-1}$, respectively. Contour interval in (b) is $0.004 \mathrm{~Pa} \mathrm{~s}^{-1}$ (standard deviation) $)^{-1}$ and negative contours are dashed.

terannual Hadley and Walker circulation anomalies over the monsoon region during a La Niña episode within this interdecadal phase are opposite to the interdecadal anomalies and essentially negate the tendency of the interdecadal oscillation to produce decreased rainfall over the Indian continent.

Thus, in a warm phase of the interdecadal SST mode, droughts are likely to be associated with El Niño events while floods are unlikely during La Niña events. Similarly, in the colder phase of the interdecadal SST variation, the Indian monsoon rainfall is unlikely to be strongly affected during El Niño events while floods could be expected during La Niña events. This physical picture helps to explain the observation that while there are epochs when El Niño events are strongly related to droughts in India, there are also epochs when El Niño events and droughts are not as strongly related, and also explains why the correlation between eastern Pacific SST and IMR is not very strong. In one phase of the interdecadal oscillation, El Niño events are related to droughts but the La Niña events are not related to floods, 

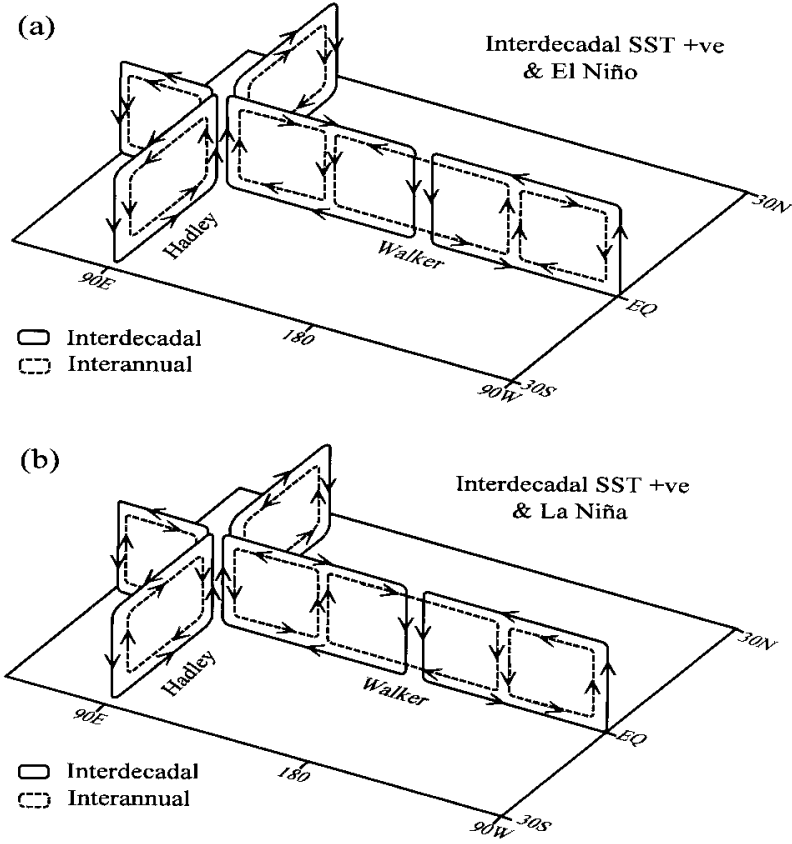

FIG. 18. Schematic representation of monsoon-ENSO interaction as a combined effect of the interdecadal and interannual modes. The regional Hadley circulation and the Walker circulation associated with one phase of the interdecadal mode (positive eastern Pacific phase of the interdecadal SST variation) are shown in solid lines. The regional Hadley and Walker circulation associated with two extremes [(a) El Niño and (b) La Niña] of the interannual variations (dashed lines) are superposed on the interdecadal mode.

and the situation reverses in the other phase of the interdecadal oscillation. As neither phase of the interdecadal oscillation favors increased or decreased correlation between the monsoon and eastern Pacific SST, the interdecadal oscillation does not modulate the correlation between the monsoon and Pacific SST on the interannual timescale. This relation also explains why the changes in the interannual correlations (Fig. 5) lack correspondence with the interdecadal variability of IMR or Niño-3 (Fig. 1).

\section{Conclusions}

Both the Indian summer monsoon and Pacific SST are known to have interdecadal oscillations. As shown by Kripalani and Kulkarni (1997), the interdecadal variation of the Pacific SST is not simply a result of the changes in the frequency of El Niño and La Niña events. Similarly, the interdecadal variability of the Indian monsoon does not result simply from changes in the frequency of interannual droughts and floods. The interdecadal variations of both monsoon and SST appear to be of a more fundamental nature. We have presented empirical evidence to support the hypothesis that the interdecadal variations of the Indian monsoon are an integral part of a coupled monsoon-SST mode.

- Using long time series of IMR, SST, and SLP, at least
125 yr long, we showed that the low-pass-filtered IMR is strongly correlated with various low-pass-filtered indices of ENSO, such as the Niño-3 SSTA index, the modified SOI based on the global SLP data, the cold tongue index (CT), the North Pacific SST index (NP), and an index of Indian Ocean SST (IO). The correlation between the low-pass-filtered IMR and equatorial indices of ENSO (e.g., Niño-3 and CT) is stronger than that with off-equatorial index NP, indicating that the interdecadal monsoon-SST mode may be a tropical coupled ocean-atmosphere mode just like its interannual counterpart.

- The global patterns of SST and SLP associated with the interdecadal variations of the Indian monsoon (the low-pass-filtered IMR) are nearly identical with those associated with the ENSO-like interdecadal variability.

- The amplitude of the interannual fluctuations of both Indian monsoon and ENSO seem to increase or decrease simultaneously and closely follow the interdecadal oscillation. For example, in the warm eastern Pacific phase of the interdecadal SST mode (or the below-normal phase of the Indian monsoon), the interannual variances of both IMR and Niño-3 SST are high while in the opposite phase of the interdecadal mode they are low.

Using the 49-yr circulation data from the NCEPNCAR reanalysis project and regressing the circulation fields upon the low-pass filtered IMR (or Niño-3) time series, we obtained the three-dimensional structure of the interdecadal monsoon-SST mode and gained insight into how the interdecadal mode influences the monsoon-ENSO relationship on the interannual timescale. Similarly, the three-dimensional structure of the interannual monsoon-SST mode was obtained by regressing the circulation fields upon the residual (interannual) IMR (or Niño-3) time series. The structure of the interdecadal mode obtained through the regression analysis was found to be similar to the structure of the dominant mode obtained by an independent combined EOF analysis of the low-pass-filtered circulation fields. The vertical structure of the interdecadal mode in the equatorial region is first baroclinic, similar to its interannual counterpart. This similarity between the interdecadal and interannual mode should probably be expected as the SST patterns (and hence the atmospheric heating distribution) associated with the two modes are known to be similar. We showed that both the regional Hadley circulation anomalies and Walker circulation anomalies associated with the strong (weak) phases of the interdecadal oscillation are similar to those associated with the strong (weak) phases of interannual variability over a considerable part of the equatorial region. We also showed that the strength of the anomalous Hadley circulation associated with the interdecadal variability is comparable to that associated with the interannual variability. 
There are several strong and weak phases of interannual variations within a particular phase of the interdecadal oscillation. During a warm eastern Pacific phase of the interdecadal SST variation, the regional Hadley circulation associated with El Niño reinforces the prevailing anomalous interdecadal Hadley circulation while that associated with La Niña opposes the prevailing interdecadal Hadley circulation. Therefore, during the warm phase of the interdecadal oscillation, El Niño events are expected to be strongly related to monsoon droughts while La Niña events may not have a significant relation. On the other hand, in the cold eastern Pacific phase of the interdecadal oscillation, La Niña events are more likely to be related to monsoon floods while El Niño events are unlikely to have a significant relation with the Indian monsoon. Thus, there is a fundamental reason why the monsoon-ENSO relation is not very strong on the interannual timescale. In either phase of the interdecadal oscillation, only one phase of the interannual variation reinforces the local Hadley circulation while the other phase almost cancels the interdecadal Hadley circulation. Whenever, the interdecadal and the interannual Hadley circulations reinforce each other, the coupled mode (or boundary forcing) is strong and may overcome the effects of the internal dynamics. On the other hand, when the interdecadal and interannual Hadley circulations oppose each other in the monsoon region, internal processes may govern the state of the Indian monsoon.

Acknowledgments. V. Krishnamurthy was supported by grants from the National Science Foundation (ATM9321354), the National Oceanic and Atmospheric Administration (NA76-GP0258), and the National Aeronautics and Space Administration (NAGW-5213). B. N. Goswami acknowledges partial support by a grant from the Department of Science and Technology, Government of India, and also thanks J. Shukla for hospitality during a visit to COLA while this study was in progress. The authors thank Kikuro Miyakoda for useful comments and Tracy Basnett for providing the GMSLP2 dataset.

\section{REFERENCES}

Allan, R. J., 1993: Historical fluctuations in ENSO and teleconnection structure since 1879: Near global patterns. Quat. Australasia, 11, 17-27.

—, J. A. Lindesay, and C. J. C. Reason, 1995: Multidecadal variability in the climate system over the Indian Ocean region during austral summer. J. Climate, 8, 1853-1873.

,-- , and D. E. Parker, 1996: El Niño Southern Oscillation and Climatic Variability. CSIRO Publishing, 405 pp.

Basnett, T. A., and D. E. Parker, 1997: Development of the global mean sea level pressure data set GMSLP2. Climate Research Tech. Note 79, 54 pp. [Available from Hadley Centre, Meteorological Office, London Road, Bracknell, Berkshire RG12 2SY, United Kingdom.]

Gershunov, A., and T. P. Barnett, 1998: Interdecadal modulation of ENSO teleconnections. Bull. Amer. Meteor. Soc., 79, 27152725.
Goswami, B. N., 1998: Interannual variations of Indian summer monsoon in a GCM: External conditions versus internal feedbacks. J. Climate, 11, 501-522.

_ - V. Krishnamurthy, and H. Annamalai, 1999: A broad scale circulation index for the interannual variability of the Indian summer monsoon. Quart. J. Roy. Meteor. Soc., 125, 611-633.

Graham, N. E., 1994: Decadal-scale climate variability in the 1970s and 1980s: Observations and model results. Climate Dyn., 10, $135-162$.

— , T. Barnett, R. Wilde, M. Ponater, and S. Schubert, 1994: On the roles of tropical and midlatitude SSTs in forcing interannual to interdecadal variability in the winter Northern Hemisphere circulation. J. Climate, 7, 1416-1441.

Gu, D., and S. G. H. Philander, 1997: Interdecadal climate fluctuations that depend on exchanges between Tropics and extratropics. Science, 275, 805-807.

Joseph, P. V., 1976: Climate change in monsoon and cyclones 18911974. Proc. Symp. Tropical Monsoons, 378-387. [Available from Indian Institute of Tropical Meteorology, Homi Bhabha Road, Pune 411008, India.]

Kachi, M., and T. Nitta, 1997: Decadal variations of the global oceanatmosphere system. J. Meteor. Soc. Japan, 75, 657-675.

Kalnay, E., and Coauthors, 1996: The NCEP-NCAR 40-Year Reanalysis Project. Bull. Amer. Meteor. Soc., 77, 437-471.

Kaplan, A., Y. Kushnir, M. A. Cane, and M. B. Blumenthal, 1997: Reduced space optimal analysis for historical data sets: 136 years of Atlantic sea surface temperatures. J. Geophys. Res., 102C, $27835-27860$.

Kawamura, R., 1994: A rotated EOF analysis of global sea surface temperature variability with interannual and interdecadal time scale. J. Phys. Oceanogr., 24, 707-715.

Knutson, T. R., and S. Manabe, 1998: Model assessment of decadal variability and trends in the tropical Pacific Ocean. J. Climate, 11, 2273-2296.

Kripalani, R. H., and A. Kulkarni, 1997: Climatic impact of El Niño/ La Niña on the Indian monsoon: A new perspective. Weather, $\mathbf{5 2}, 39-46$.

- — - and S. V. Singh, 1997: Association of the Indian summer monsoon with the Northern Hemisphere mid-latitude circulation. Int. J. Climatol., 17, 1055-1067.

Latif, M., 1998: Dynamics of interdecadal variability in coupled ocean-atmosphere models. J. Climate, 11, 602-624.

- , R. Kleeman, and C. Eckert, 1997: Greenhouse warming, decadal variability, or El Niño? An attempt to understand the anomalous 1990s. J. Climate, 10, 2221-2239.

Mann, M. E., and J. Park, 1993: Spatial correlations of interdecadal variation in global surface temperatures. Geophys. Res. Lett., 20, $1055-1058$.

— , and — 1994: Global-scale modes of surface temperature variability on interannual to century timescales. J. Geophys. Res., 99D, 25 819-25 833.

— perature and sea level pressure variability in the Northern Hemisphere during the last century. J. Climate, 9, 2137-2162.

,- -, and R. S. Bradley, 1995: Global interdecadal and centuryscale climate oscillations during the past five centuries. Nature, 378, 266-270.

Meehl, G. A., J. M. Arblaster, and W. G. Strand Jr., 1998: Global scale decadal climate variability. Geophys. Res. Lett., 25, 39833986.

Mehta, V. M., and K.-M. Lau, 1997: Influence of solar irradiance on the Indian monsoon-ENSO relationship at decadal-multidecadal timescales. Geophys. Res. Lett., 24, 159-162.

Nigam, S., 1994: On the dynamical basis for the Asian monsoon rainfall-El Niño relationship. J. Climate, 7, 1750-1771.

Pant, G. B., and B. Parthasarathy, 1981: Some aspects of an association between the Southern Oscillation and Indian summer monsoon. Arch. Met. Gaffes. Biokl., 1329, 245-252.

- H. P. Borgaonkar, and K. Rupa Kumar, 1995: Climate during 
the past 250 years over the western Himalayas: A dendroclimatic reconstruction. Mem. Geolog. Soc. India, 32, 78-97.

Parthasarathy, B., and G. B. Pant, 1985: Seasonal relationship between Indian summer monsoon rainfall and Southern Oscillation. J. Climatol., 5, 369-378.

— - K. Rupa Kumar, and A. Munot, 1993: Homogeneous Indian monsoon rainfall: Variability and prediction. Proc. Ind. Acad. Sci. (Earth \& Planet. Sci.), 120, 121-155.

— , A. A. Munot, and D. R. Kothawale, 1994: All Indian monthly and seasonal rainfall series: 1871-1993. Theor. Appl. Climatol., 49, 217-224.

,-- , and -1995 : Monthly and seasonal rainfall series for all India, homogeneous regions and meteorological subdivisions: 1871-1994. Research Report No. RR-065, 113 pp. [Available from Indian Institute of Tropical Meteorology, Homi Bhabha Road, Pune 411008, India.]

Rasmusson, E. M., and T. H. Carpenter, 1983: The relationship between eastern equatorial Pacific sea surface temperature and rainfall over India and Sri Lanka. Mon. Wea. Rev., 111, 517-528.

Shukla, J., 1987: Interannual variability of monsoons. Monsoons, J. S. Fein and P. L. Stephens, Eds., Wiley and Sons, 399-464.
—, and D. A. Paolino, 1983: The Southern Oscillation and longrange forecasting of the summer monsoon rainfall over India. Mon. Wea. Rev., 111, 1830-1837.

Sikka, D. R., 1980: Some aspects of the large scale fluctuations of summer monsoon rainfall over India in relation to fluctuations in the planetary and regional scale circulation parameters. Proc. Ind. Acad. Sci. (Earth \& Planet. Sci.), 89, 179-195.

Tanimoto, Y., N. Iwasaka, K. Hanawa, and Y. Toba, 1993: Characteristic variations of sea surface temperature with multiple time scales in the North Pacific. J. Climate, 6, 1153-1160.

Webster, P. J., 1987: The variable and interactive monsoon. Monsoons, J. S. Fein and P. L. Stephens, Eds., Wiley and Sons, 269-330.

_ systems. Quart. J. Roy. Meteor. Soc., 118, 877-926.

, V. O. Magaña, T. N. Palmer, J. Shukla, R. A. Tomas, M. Yanai, and T. Yasunari, 1998: Monsoons: Processes, predictability, and the prospects for prediction. J. Geophys. Res., 103C, 14 45114510.

Zhang, Y., J. M. Wallace, and D. S. Battisti, 1997: ENSO-like interdecadal variability: 1900-93. J. Climate, 10, 1004-1020. 